Portland State University

PDXScholar

12-10-1997

\title{
Vormärz of Germany and The Critique of Heinrich Heine
}

Andrew Dean Henley

Portland State University

Follow this and additional works at: https://pdxscholar.library.pdx.edu/open_access_etds

Part of the European History Commons, Political History Commons, and the Social History Commons Let us know how access to this document benefits you.

Recommended Citation

Henley, Andrew Dean, "Vormärz of Germany and The Critique of Heinrich Heine" (1997). Dissertations and Theses. Paper 5372.

https://doi.org/10.15760/etd.7245

This Thesis is brought to you for free and open access. It has been accepted for inclusion in Dissertations and Theses by an authorized administrator of PDXScholar. Please contact us if we can make this document more accessible: pdxscholar@pdx.edu. 


\section{THESIS APPROVAL}

The abstract and thesis of Andrew Dean Henley for the Master of Arts in History were presented October 13, 1997, and accepted by the committee and the department.

COMMITTEE APPROVALS:

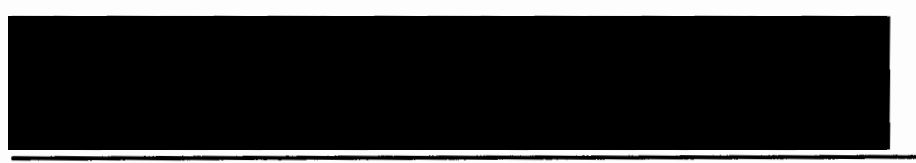

Sean Dobson, Chair

Susan Karant-Nunn

Michael Reardon

Louis Elteto

Representative of the Office of Graduate Studies

DEPARTMENT APPROVAL:
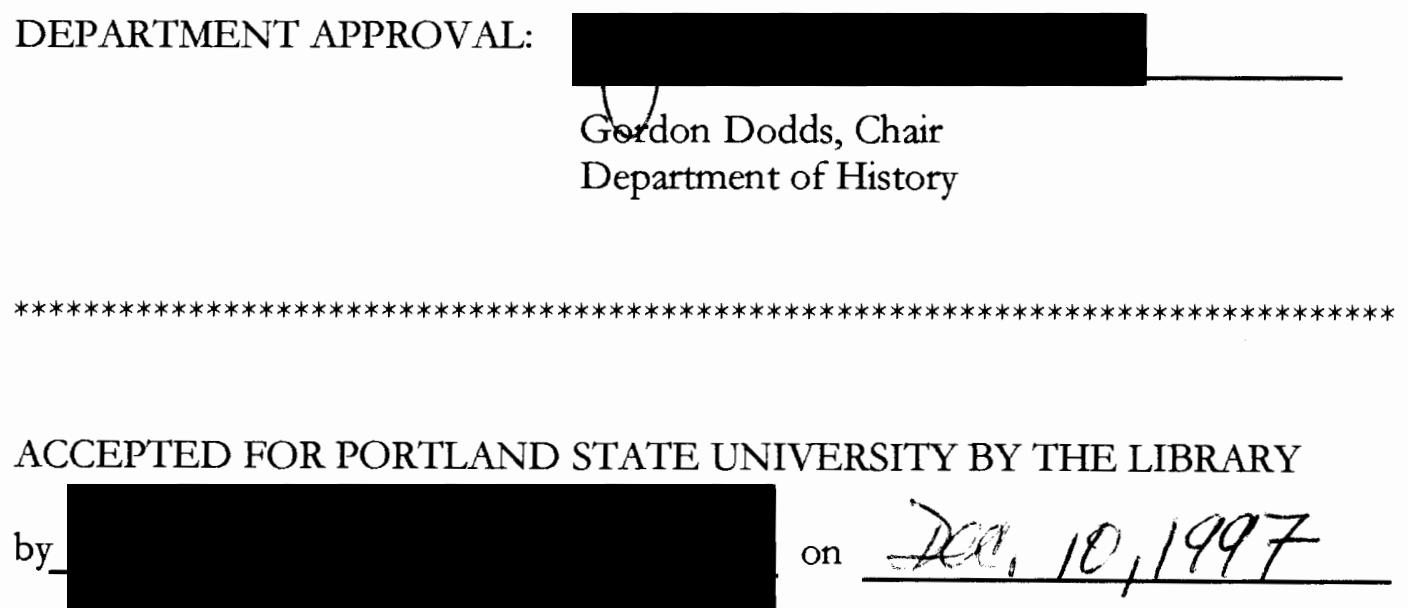


\begin{abstract}
An abstract of the thesis of Andrew Dean Henley for the Master of Arts in History presented October 13, 1997.
\end{abstract}

Title: Vormärz Germany and the Critique of Heinrich Heine.

The conclusion of the French Revolution and the Napoleonic Wars marked the beginning of the modern world. In western Europe new ideals about the position of the individual and the future of society flourished in the early nineteenth century--prior to the revolutions of 1848 . However, the forward move into the modern world was stymied in the multitude of states which composed Germany after 1815. Due to a combination of factors-political repression, conservative/romantic trends, social lethargy, and liberal immaturity--German society in the period 1815-1848--the Lormärz (pre-March 1848) clung to traditional ways. The most famous German writer of this period, Heinrich Heine, developed a unique understanding of this situation. He grasped the fundamental paradoxes of his age and forced them upon an often unwilling audience. Heine was an atypical figure in German society--an outsider who commanded great attention and whose insight in to the nature of German society was colored by his own individual conceptions which encompassed the breadth and multifaceted character of German and European history. His social and political commentary made him many enemies and detractors--both on the Left as well as the Right. Heine's most famous satirical poem, Deutschland: Ein Wintermärchen, has been identified as the pinnacle critique of Vormäry Germany. In the epic poem Heine illuminates the fundamental 
flaws of his beloved motherland, while simultaneously expounding his larger conceptions of history and the possible future. Heine's gifts as a writer allowed him to create a work which is at once both a commentary on the state of German society during the Vormärz and an investigation into his own peculiar position within and outside of his own culture. 
VORMÄRZ GERMANY AND THE

CRITIQUE OF HEINRICH HEINE

by

ANDREW DEAN HENLEY

A thesis submitted in partial fulfillment of the requirements for the degree of

\section{MASTER OF ARTS}

in HISTORY

Portland State University

1997 
Table of Contents

\section{Chapter 1}

THE ADVENT OF THE MODERN WORLD.............................................. 1

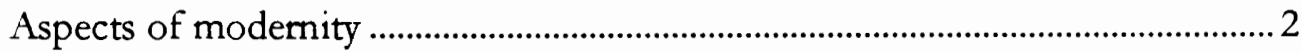

Chapter 2

THE CONTEXT OF THE GERMAN VORMÄRZ ……..........................

The Congress of Vienna and the Fate of the German Lands................................ 9

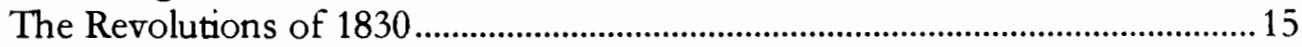

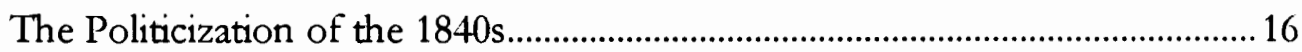

Changes in Society …………………………………………................................ 19

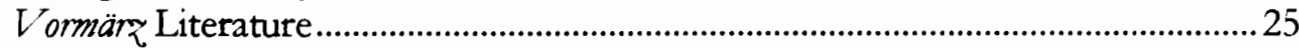

Chapter 3

HEINE: THE SPECTRUM OF VORMÄRZ EXPERIENCE ..................34

Heine the Outsider................................................................................................ 35

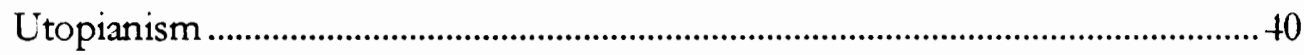

Nazarenism vs. Hellenism.................................................................................... 55

Napoleon and Revolution ...................................................................................57

German Pantheism and German Philosophy........................................................6 60

Heine and the Vormärz .........................................................................................64

Chapter 4

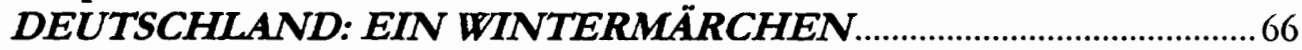

The Composition of Deutschland: Ein Wintermärchen .............................................66

Medieval vs. Modem.............................................................................................

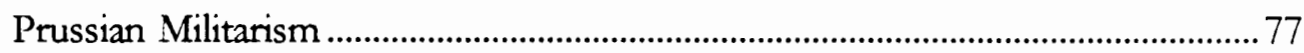

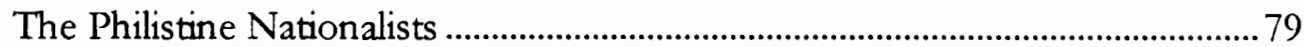

The Radicals and Party Politics ............................................................................... 82

The French Revolution and Modernity ................................................................... 84

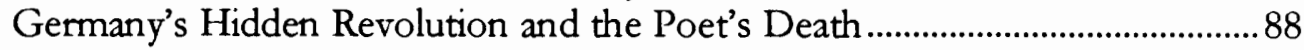

The Future of Germany and the Faltering of Heine's Idealism ........................... 90

Heine's Warning .................................................................................................... 92

Chapter 5

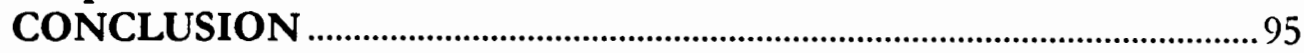

Heine in the Vormärz............................................................................................. 100 


\section{THE ADVENT OF THE MODERN WORLD}

What we understand as the modem world came into existence after the conclusion of the Napoleonic Wars. The French Revolution and Napoleon's conquests were the fateful events which forced upon a reluctant monarchical Europe the results and consequences of the Enlightenment. ${ }^{1}$ Concepts of rationality and humanism, which had been in the process of development since the Renaissance, were thrust upon the greater European world through a quarter century of social disruption and violence. Accordingly, revolution and war were to have significant impact on the more backward areas of Europe, particularly the fragmented German speaking countries - the core of the thousand year-old Holy Roman Empire. In these areas the turmoil of French invasion and occupation were accompanied by equally strong, if not more powerful forces--new ideas and radical concepts about the natural order of society and the role of the individual. Centuries old traditions and customs were swept away by the conquering French. The medieval walls which had once protected the cultural and economic centers of Germany had disappeared in the previous two centuries prior to Napoleon, yet the semi-medieval

\footnotetext{
${ }^{1}$ Paul Johnson, The Birth of the Modern: World Society 1815-1830, (New York: Harper Collins, 1991), p. xvii.
} 
structure of society still remained for the French to dismantle, which they attempted to do with bureaucratic efficiency and the Code Napoléon. The defeat of $l$ 'Empereur and the reinstitution of the Bourbon monarchy in France did not erase the legacy of the Revolution for Europe and life did not return to the status quo ante bellum. After 1815 a new era dawned for much of Europe. The process of modemization took decades and not all areas developed at the same pace. For much of western Europe the ancien régime ended sometime during 1789 and 1815 , yet for Germany it continued in a weakened existence until the revolutions of 1848. For Europe and for Germany the first years after the Congress of Vienna were a time of uncomfortable transition marked by obvious discrepancy and contradiction. ${ }^{2}$

\section{Aspects of modernity}

There are many elements which differentiate the modem world from that of the ancien régime. On the social level, the latter was characterized by a rigidly hierarchical class structure in which each person had a corporate identity --within a guild, a feudal rank, or any other group which retained special privileges and rights. The French Revolution had disseminated the notion of individual rights and freedoms, and although such equality was not instituted in every comer of French influence, the concept, nonetheless, filtered its way through society. By and large, this idealism was exported by the French

2 Rudolf Vierhaus, "Vormärz'--ökonomische und soziale Krisen, ideologische und politische Gegensätze," Francia, 13 (1985), 355. 
middle-class and adopted by its counterparts in other countries, who had also been in the process of developing since the eighteenth century. Indeed, the rapid expansion of the wealth and influence of the middle-class in the early nineteenth century is truly one of the first manifestations of the modern era. Although it would not be until the reign of Louis Phillipe in France after 1830 and the Reform Bill in Britain in 1832 that any European middle-class attained a political voice, across Europe the middle-class was establishing itself as the dynamic cultural force in the first third of the nineteenth century--defining popular tastes in fashion, music, and literature. Coupled with the rise of the middle-class were the economic forces which were responsible for its ascent-early capitalism and rudimentary industrialization. ${ }^{3}$ The subsistence economy of the ancien regime was replaced by ever more efficient and specialized production. Mass production of commodities such as iron led to the creation of the greatest symbol of the modern world--the railroad. ${ }^{4}$ Yet the Industrial Revolution was only in its early phase. It would not be until much later in the nineteenth century that railroads and other such manifestations of the new economy would accelerate the pace of life beyond anyone's expectations.

Alongside these developments of the early nineteenth century is another factor which has come to define the modern world--urbanization.

\footnotetext{
3 It is important to note that capitalism and industrialization first evolved in Britain and France and that most other areas of Europe were many decades behind. This is especially true of Germany.

${ }^{4}$ The first railroad in Germany was built in 1835 .
} 
Although this process began much earlier, urbanization reached unprecedented proportions after 1815. Increased specialization and production in agriculture coupled with the loosening of seigniorial bonds released untold numbers of peasants from rural areas. In the nineteenth century many emigrated overseas, but many more emigrated intemally--either into under-populated farmlands or into cities. These people created a surplus labor force as well as much concern for their social betters. The first decades after Napoleon were a time of increased insecurity for much of the population. Widespread famine did not end until the mid 1840s, and al though new jobs were created in factories, there was still chronic under-employment. As a consequence there was much social tension, especially in regards to the labor force. The new urban based labor class--the proletariat--was in the first stages of its development and the strength of the traditional guild workers was in noticeable decline. The middle-class, the infant proletariat, and the guild workers all yeamed for security. In Germany the remnant pre-modern social and political structure could not accommodate change. ${ }^{5}$

5 Theodore S. Hamerow, Restoration, Revolution, Reaction: Economics and Politics in Germany, 1815-1871, (Princeton: Princeton University Press, 1958), p. 58. 
Traditional Europeans lived in a world of immediate uncertainty but long term continuity; if they survived, they could assume that tomorrow would be much like today. For moderns the opposite seemed to be true: slowly and painfully, they acquired some measure of control over their personal lives, but they had to live in a world where basic change was permanent and inescapable. ${ }^{6}$

The large scale uncertainty brought about by the emergence of the modern world caused a cultural and intellectual backlash across Europe. Not everyone understood nor embraced the new modes of life. This was especially true for much of German society, which had not fully completed revolutionary change as the French had done, or had the unique experience of insular Britain. The period after Napoleon was for Germany a time of superficial calm, but growing unrest. Discontent was pacified by a reactionary political system and a cultural propensity towards conservatism. However, not all Germans feared and detested the changes of modernity. Progressive elements existed on the fringes. A particular characteristic of this era is that these radical elements found a public voice. The printed word was the most dangerous weapon in the arsenal of the opposition. Those individuals and groups unhappy with the state of affairs carried out subversive campaigns using the press and the printer. The powers of the status quo feared these discontented literati.

For the greater part of his active life the famous poet/author Heinrich Heine (1797-1856) was considered an active member of the opposition. He was not politically radical, but he wholeheartedly welcomed the new era and all

${ }^{6} J a m e s$ J. Sheehan, German History, 1770-1866, (Oxford: Clarendon Press, 1989), p. 453. 
its changes--often lambasting the conservative elements of his culture for their failure to embrace historical progression. He posed himself as the first man of the new century--enlightened and progressive--the antithesis of the status quo. Heine possessed great insight and he recognized that life had fundamentally altered for Europeans after 1789. He rejoiced in the promise of the future, and he harshly ridiculed what he saw as anachronism in his homeland. A figure well versed in the philosophy of his day, Heine was able to formulate an encompassing Weltanschaung (world-view) which took in the entire scope of German history and philosophy and with this was able to present to his audience an elaborate, yet often contradictory, opinion of what the world could and should be. In very Hegelian terms, Heine believed, "Wenn man den Himmel revolutioniert, kann die Erde nicht rubig bleiben" (When heaven is revolutionized, the earth cannot remain calm. $)^{7}$ He saw that in the realm of idealism the westem world after Napoleon was definitely in an uproar. Heine also saw that in the emerging modem world the Germans were resisting modernity. Heine believed he was the artist most capable of bringing Germany into the modem world, although in doing so he estranged himself not only from the ruling powers, but also from all others who also believed to be their task to wrestle Germany in to the modern era--the other progressives. Heine's satirical style captured the irony of his age as well as his own particualr conceptions of

\footnotetext{
7 Thomas Nipperdey, Germany from Napoleon to Bismarke, (Princeton: Princeton University Press, 1983), p. 358.
} 
modemity. German society abounded in paradoxes during the Vormär and Heine was quick to point these out and reflect them in the warped mirror of irony. However, Heine was anything but a one-dimentional character. Deep rooted contradictions within his personality flavor his writings with unreconsilable paradoxes, quite akin to those which he ridiculed. The works in which he unleashes his most vile venom attack not only the enemies of modemity but also many of its proponents. There is an unmistakable sense of dread for what he sees as the possible dangers of modernity. Heinrich Heine was not a typical man of his times. He was extraordinary. Yet Heine was a figure who almost embodied his era. He recognized the changes of the present, hoped and feared for the future, yet he often felt himself to be a being of the past. The transitional nature of the Vormärz found itself contained within the psyche of one man. As a consequence, Heine's critique of his era holds a special authenticity and perspective quite unlike any of his contemporaries. 
Chapter 2

\section{THE CONTEXT OF THE GERMAN VORMÄRZ}

For German history the period between the Congress of Vienna and the outbreak of revolution in 1848 has been labeled the Vormärz--the preMarch (1848). ${ }^{8}$ As previously stated, the period after the French Revolution and Napoleon was characterized by massive social change for most of Europe and especially Germany. Consequently, it is easiest to understand the German Vormärz as a time of transition--the closing phase of the old world when the seeds of modemity germinated.' The peculiarity of the era lies in its contradictions. The Vormärz witnessed large-scale social and cultural change, yet it was also a time of political stagnation and repression. Much of German culture during the Vormärz rejected the modem world, while other elements embraced it and worked to expedite political reforms which would accommodate the changes in society and culture. The experience of revolution and war had quickly moved Germany into the modem era; the Vormärz was the period in which Germany reacted to the change.

\footnotetext{
${ }^{8}$ The period has also been labeled the Restorationsepoche (restoration epoch). This label is lacking in that for many historians the Restoration was a specific political policy which grew out of the Congress of Vienna and does not necessarily reflect the true dynamic of the period. Vormär, as an historical label, is somewhat confusing as well because it derives from an event which marked the close of that period. For this study the term Vormär is used exclusively for the reason that it is sufficiently general to encompass numerous aspects of the era outside of politics.
} 


\section{The Congress of Vienna and the Fate of the German Lands}

The political situation during the thirty-three years of the Vormärz was shaped by the Restoration of 1814-15. The reactionary policies and institutions which were enacted after Waterloo remained in place in Germany for an entire generation, despite efforts at progressive reform. When the powers of Europe, great and small, met in Vienna it was their intention to stabilize Europe so that there would never again be a threat to the status quo from any one power or from revolution. The old order may have been dying, but the Habsburgs, Romanovs, and Hohenzollems were still in control of the political situation in central Europe. At Vienna they wished to consolidate their position and repair any damage done to the bukwark of the monarchical principle.

Only the less astute participants of the Congress thought that the clock could be tumed back and institutions such as the Holy Roman Empire restored. Those who fully understood the tremendous impact of the Revolution and Napoleon could not be so optimistic. The chief architect of the Congress, Prince Klemens von Metternich, was openly pessimistic about the future, for he recognized that new social and cultural forces had been unleashed since 1789 and that there would be no return to the past. ${ }^{10}$ The old world was at the beginning of the end. Metternich recognized the power and danger inherent in the new social and political awakening, although he spent

9 Vierhaus, "Vormärz," 367. 
most of his life attempting to suppress such impulses. As Metternich later admitted in 1848, the house of Europe was rotten and no amount of support could keep it from falling down. New ideas had permeated too deeply into the psyche of Europe. ${ }^{11}$

In the context of the political restructuring of Europe, the situation in Germany was one of the primary concerns of the Vienna Congress. In fact, the "German Question" was one of the most difficult problems of diplomacy, at one point almost disrupting the successful conclusion of the Congress. ${ }^{12}$ Napoleon had altered the physical condition of Germany drastically in his attempt to consolidate his position in central Europe. He had reorganized the western half of Germany into the Confederation of the Rhine, forever erasing from the map numerous ecclesiastical states and principalities of the defunct Holy Roman Empire. In 1814-15 these deposed rulers wanted a reinstatement of their holdings, but the medium-sized states which Napoleon had created were unwilling to part with the territories they had acquired under French rule. ${ }^{13}$ Also, the major powers at Vienna recognized the futility of any such action. Metternich and others found the new expanded states, such as Württemberg, more desirable in terms of political balance, so they were kept,

\footnotetext{
${ }^{10}$ Sheehan, German History, p. 392.

11 Ibid., p. 392.

12 Ibid., p. 397.

${ }^{13}$ Ibid, p. 399.
} 
with limited alterations. Germany remained splintered, but not to the extreme degree it had been before. Prussia and the Habsburg Empire remained the largest powers in the central Europe, and the middle states were to act as buffers between them. ${ }^{14}$

The Kingdom of Prussia, which had been growing in power and size since the early eighteenth century, was compensated and enlarged for its efforts in resisting and helping to defeat Napoleon. It was given Posen in the east and the Rhineland in the west, as well as much of Saxony and various other territories in the north. This addition dramatically increased the geographical size and population of Prussia. However, not all of the lands attached to Prussia in $1814-15$ were similar to the traditional Protestant Hohenzollem core territories. The majority of the inhabitants in Posen were Polish. The Rhineland was predominantly Catholic and very much influenced by the French, who had occupied it since 1801. This heterogeneous configuration would bring much difficulty to the Prussian state during the Vormär: Not all of the inhabitants of the newly acquired territories were content to live under its reactionary rule. The addition of the westem German areas would later become a significant factor in Prussia's economic predominance in Germany, and its later political hegemony. ${ }^{15}$

\footnotetext{
${ }^{14}$ Tbid., p. 401.

15 Nipperdey, Germany from Napoleon to Bismanck. p. 75.
} 
The Habsburgs, the traditional rulers of the Holy Roman Empire, were still the most powerful political entity in Germany after the Congress of Vienna. They did not look for territorial compensation to their north, but instead in the Italian peninsula. Yet Metternich was still concerned with the German situation. He believed a balance of power coupled with a political mechanism to guide German affairs was necessary for peace and stability in central Europe. His solution was the Germanic Confederation--a federal organization of thirty-nine autonomous states. ${ }^{16}$ Its charter read that the member states combined to make "eine in poltischer Einheit verbundene GesamtMachl' (a politically unified confederated power). ${ }^{17}$ Its congress in Frankfurt-the Bundesversammlung - was to work for the maintenance of the internal and external security of Germany, and the independence and inviolability of the member states. The Habsburgs retained political control of the Bundesversammlung and steered German policy for the entire era.

The Confederation was to be the tool of reaction during the Vormär: It would have moments of weakness, but would, nevertheless, function for half a century. Metternich created a stable system in which "everything happened only so that nothing would happen."18 Member states cooperated to quell

\footnotetext{
16 The Germanic Confederation lasted until 1866. The number of member states eventually dropped to 34. Sheehan, German History, p. 403.

17 Ibid., p. 409.

${ }^{18}$ Hans-Georg Wemer, Geschichte des politischen Gedichts in Deutschland von 1815 bis 1840, (Berlin: AkademieVerlag, 1969), p. 191. "in dem alles nur geschah, damit nichts geschehe."
} 
discontent and seek out sources of subversion. Political clubs, local assemblies, student fratemities (the famous Burschenschaften), essayists, pamphleteers, journalists, and poets were all subject to state scrutiny and censorship. Revisionist nationalists were identified as the primary enemies of the Confederation. ${ }^{19}$ Pan-Germanic nationalism, the broadest of all the Vormär social movements, had its roots in the Wars of Liberation and the student movement. After the culmination of nationalist sentiment in the Wartburg Festival of 1817 and the consequent state investigations, many reform-minded Germans came to associate progress with national unification and the Confederation with political and economic stagnation..$^{20}$

In 1819 the Confederation, under the direction of Mettemich, enacted the Karlsbad decrees, which singled out the student Burschenschaften as a specific target for repression because of their propensity for nationalistic subversion. The Karlsbad decrees also enacted strict censorship of printed material under 320 pages. ${ }^{21}$ A confederal investigation bureau was created to watch for sedition among the populace. In 1820 the original Bundeasakte (confederal act) of the Confederation was amended with the Wiener Schlussakte (Vienna finalizing act), which called for the Confederation's intervention in any state's domestic affairs if public order was considered to be in jeopardy. The

\footnotetext{
19 Wolfram Siemann, Die dewtsche Revolution von 1848/49, (Frankfurt am Main: Suhrkamp, 1985), p. 39. 20 Sheehan, German History, p. 410.
} 
Schlussakte also created policies which severely hindered the creation of constitutions in any of the member states. These reactionary measures drew to a close the era of state reform in Germany which had begun during the last years of the Napoleonic era under the leadership of men like Stein and Hardenberg in Prussia. ${ }^{22}$ Other reactionary measures followed in 1832 and 1834. The combination of federal and state repression often radicalized the opposition groups of the Vormärz as much as it hindered them. The political solution of Vienna and the conservatism of the Confederation did not effectively quell discontent.

Another of the chief issues confronting the Confederation throughout the Vormärz was that of constitutions for the member states. ${ }^{23}$ Article XIII of the Bundesakte decreed that the confederated states were each to develop constitutions, yet only the southern and westem states created such documents, despite the efforts of Mettemich at diverting those impulses. ${ }^{24}$ Also, during the Wars of Liberation many of the German princes, such as King Friedrich III of Prussia, promised constitutions for their lands in order to gain the cooperation of the populace. Such promises went unfulfilled after 1815 . In 1837 a group of seven famous professors in Göttingen lost their positions

\footnotetext{
${ }^{21}$ The most reactionary states, Prussia, Hanover, and the Habsburg Empire, pre-censored all books regardless of their page number. Siemann, Die deutsche Rerolution, p. 40.

22 Vierhaus, "Vormärz," 356.

23 Ibid., 358.

${ }^{24}$ Nipperdey. Germany from Napoleon to Bismanck, p. 238.
} 
because they publicly called for the King of Hanover to honor his obligation and grant that kingdom a constitution. These men, most notably the Grimm brothers, were hailed by many Germans as heroes in the cause of freedom. By the end of the Vormarz the constitutional question escalated in to one of the primary reasons for the discontent of the middle-class and their initial support of the revolution in 1848 .

\section{The Revolutions of 1830}

In the previous generation Alexis de Tocqueville had postulated that revolution is more than a single historical event, rather it is a larger encompassing process which leads to sharper polarization of differing political currents and a greater dynamic of total political life..$^{25}$ The July Revolution in Paris proved to Germany and the world that revolution was not dead. The ascension of Louis Philippe and his coronation as "King of the French" ushered in a period of liberalization and bourgeois prosperity for Germany's western neighbor. Events in the Confederation never escalated to popular revolution, but a series of uprisings, inspired by France, in Hanover, HesseKassel, Saxony, and Brunswick led to the creation of new constitutions in those lands. Also in 1830 liberals in the lower chambers of parliament in Bavaria and Baden pushed through legislation favorable to their demands. It was in that year that the reactionary system created at Vienna suffered its first

25 Vierhaus, "Vormärz," 357. 
real setback. In many ways, the year 1830 marked the decisive beginning of an opposition movement in Germany. ${ }^{26}$ A pan-German manifestation of opposition, the Hambach Festival of 1832, prompted immediate reprisals by the Confederation. The counter-attack on the opposition escalated in the censorship laws of 1834 and the banning of all literature created by the "radicals" of the left--Junges Deutscbland. The Germanic Confederation attempted to quiet all forms of opposition and activism--especially any which questioned the monarchical principle.

Not only were the national unity movement and other such impulses which emphasized the principle of popular sovereignty and republicanism repressed, but also critiques of religion and reevaluations of traditional morality, as well as glorification of the French Revolution, the Polish freedom-fighters, and the Greek war of independence. ${ }^{27}$

\section{The Politicization of the 1840 s}

The 1830 s were for Germany a time of growing political awareness. In accordance with Tocqueville's dictum on the nature of revolution, the 1840 s were a time in which opposition political groups developed into different parties. ${ }^{28}$ The new parties--the Conservatives, Catholics, Liberals, Democrats, and Socialists--each represented differing factions that had developed during the 1830s. Each party strove to disseminate its platform using the most

\footnotetext{
${ }^{26}$ Hajo Holbom, $A$ History of Modern Germany, 1840-1945, (Princeton: Princeton University Press, 1969), p. 23.

${ }^{27}$ Vierhaus, "Vormärz," 360.

28 Ibid, 361.
} 
modem form of communication--the mass circulation newspaper. German politics became more vocal and more directed.

The emergence of a party system changed the relationship between state and society. The Liberal picture - of the state and the conservatives on one side, society and the Liberals on the other - became blurred. Instead, there was now a plurality of ideas and interests in society. Parties became intermediary organs between society and state; they articulated the views and the will of forces within society, and sought to make them count. $^{29}$

Across Germany public political debate intensified due to the active press as well as the influence of exiled political writers whose works were widely circulated despite their proscription. Among the topics which drew the most attention in the 1840 s was the idea of a national parliament to replace the Bundesversammlung in Frankfurt. Yet the emergence of political parties and the politicization of the population did not directly equate to political representation for many Germans. Prussia, in particular, had no form of national assembly, only local assemblies with very limited powers and limited suffrage. There was also no attempt made by the ruling princes of Germany to create a pan-German assembly. The tensions that were created out of this situation would come to a head in 1848 .

The year 1840 also witnessed the ascension of Friedrich Wilhelm IV to the throne of Prussia. Initially there was much jubilation among the progressive elements across Germany, for it was commonly believed that the

${ }^{29}$ Nipperdey, Germany from Napoleon to Bismark, p. 335. 
new king would inaugurate a period of modernization and liberalization for one of Germany's largest and most conservative states. Friedrich Wilhelm IV did pardon many political prisoners and relax censorship laws, but he was not a liberal. Surrounded by conservative advisors, the self-named Camarilla, the Prussian king ignored the repeated calls for the constitution promised by his father. This led to an increased estrangement between the crown and the liberal members of the middle-class, who constituted the majority of the extensive Prussian bureaucracy. In 1847, when Friedrich Wilhelm called for a united diet of the Prussian lands in order to underwrite a state loan for railway expenditures, the middle-class representatives of the diet united with the bureaucracy in opposition to the king in demanding a constitution. ${ }^{30}$ The efforts of the diet crystallized much of the middle-class public in favor of permanent political representation, and the entire affair tumed out to be a gross miscalculation by the king. It ended in stalemate and the diet was dismissed. $^{31}$

In addition to the political strife in Prussia and across Germany, the 1840s also witnessed the last large-scale famine in Europe. Due to poor weather conditions the potato and grain harvests from $1845-48$ were disastrous. This led to wide-scale unrest and even looting in many parts of Germany, most

\footnotetext{
30 It should be noted that a large number of Prussian reformers were also middle-class, tenured civil strants, who since the time of state reform under Stein and Hardenberg, saw the power of the state as something more than the prerogative of the nobility and the royal family.

31 Holborn, $A$ History of Modern Germany, p. 35.
} 
notably in economically depressed Silesia. The famine exacerbated the flight of the peasants into urban centers and highlighted the inability of the German economy to recover. The famine politicized many Germans who would have normally been passive.

Another development of the 1840 s was a resurgence of German nationalism. The particularity of the phenomenon was that after $18+0$, German nationalism was characterized by a distinct anti-French accent. ${ }^{32}$ The brief war scare of 1840 , which was based upon an incorrect reading of French foreign policy, escalated the impetus of pan-Germanism. The completion of the Cologne Cathedral in 1842 and the Schleswig-Holstein question became rallying points for the movement, which, although technically illegal, was able to operate and express itself at popular singing and gymnastic festivals. ${ }^{33}$

\section{Changes in Society}

Despite the reactionary political system there were many social changes in German society during the Vormär. The new market oriented economy came to Germany, dislocating millions of peasants and guildsmen. In the eyes of the developing capitalists, the political restructuring of 1814-15 was not representative of, nor beneficial to, the emerging market-based system. In turn, the consequent process of early proto-industrialization and urbanization

\footnotetext{
32 Vierhaus, "Vormärz," 361.

33 Ibid., 361.
} 
of the Vormärz worked to undermine political authority. ${ }^{34}$ During the Vormärz the paucity of economic planning on the part of the rulers of Germany was to be a constant source of discontent among advocates of industrial growth and also among those who opposed industrialization. Social tensions that grew out of the changing economic situation came to the fore in 1848 . The creation of the Zollverein in 1834 did aid in the creation of a pan-German market economy, but not every German state would lend itself to easy integration in to a larger economy, most notably Habsburg Austria.

A second area of change during the Vormärz was agriculture. Questions of land ownership and use had been plaguing Germany since the previous century. Manorialism was dying, and in the Vormärz there was an obvious desire to create new conceptions of property ownership and peasant rights. In fact, the entire conception of peasantry was undergoing redefinition--from serfdom to wage labor. Various states attempted to facilitate changes in agricultural life, but the transition was not smooth. The new orientation of the market economy forced landholders to strive for increased productivity and competitive farming techniques. ${ }^{35}$ The application of scientific farming techniques and better land use did improve agricultural production across Germany. ${ }^{36}$ The end result of the changes in agriculture and the increase in

\footnotetext{
${ }^{34}$ Hamerow, Restoration, Revolution, Reaction, p. 4.

35 Ibid., p. 39.

${ }^{36}$ Sheehan, German History, p. 478.
} 
population during the Vormärz was to impoverish numerous peasants--to place them into an uncertain life. ${ }^{37}$ The crisis in the countryside promulgated a trend in mass migration both abroad and internally. Some peasants moved to underpopulated areas in the east, others migrated into the cities. At the time of the Congtess of Vienna $75-80 \%$ of all Germans lived outside the city and obtained their livelihood through agricultural labor. By the mid 1840s, the percentage had decreased to $66 \%{ }^{38}$ The surplus pool of labor was to create much social tension as the cities rapidly expanded to accept the influx of people.

The changes in economics and agriculture reflected and reinforced changes in the structure of society. While the peasantry was in a period of transition, so too was the middle-class, which developed into the most dynamic group within German society - characterizing the trends and impulses of the Vormärz era. Yet the middle-class was not the elite group within society. In their social make-up the various states of the Confederation embodied a combination of the traditional conservatism of a feudal/agrarian society intermixed with new elements of modernization, of which the middle-class was the chief proponent. ${ }^{39}$ Accepted fashions were more middle-class in their character than ever before, but the middle-class did not make up the majority

\footnotetext{
37 The population of Germany increased from 23.5 million in 1816 to 31.5 million in 1841 . The Habsburg territories grew from 25 million to 30 million. Vierhaus, "Vormärz," 363.

${ }^{38}$ Hamerow, Restoration, Rewolution, Reaction, p. 38. Sheehan, German History, p. 470.

39 Jürgen Kocka, "Bürgertum und bürgerliche Gesellschaft im 19. Jahrhundert: Europäische Entwicklungen und deutsche Eigenarten," Bürgertum im 19. Jahrhundert, vol. I, ed. Jürgen Kocka. (München: Deutscher Taschenbuch Verlag, 1988), p. 38.
} 
of German society - only about $10 \%{ }^{40}$. Nonetheless, everything from clothing to literature became bourgeois. Other classes within German society, including the aristocracy, mimicked the tastes of the middle-class, who received their cues from the French. ${ }^{41}$ However, the development of the middle-class was not linear and unified. It splintered into various camps during the Vormär reflecting the move from medieval Büngrtum to modem bourgeoisie. ${ }^{42}$ The capitalist middle-class, ranging from the wealthy merchant/wholesalers to the more modest investors and industrialists, were quite different from humble middle-class civil-servants, such as bureaucrats and teachers. The traditional members of the middle-class, the shopkeepers and master artisans still existed, but were in noticeable decline due to the changes in the economy. Not all of these groups held similar interests and goals, and the only element that united them was an acute interest in education and Bildung (education plus social refinement), although that itself was only attainable for the wealthiest members of the class. With the possible exception of the traditional middle-class, the bourgeoisie of the Vormärz tended to support progressive goals either within the context of the emerging economic system or the extensive bureaucratic

\footnotetext{
40 Ibid., p. 13.

${ }^{41}$ Eda Sagarra, Tradition and Revolution: German Literature and Society, 1830-1890, (New York: Basic Books, 1971), p. 23. It should be noted that middle-class tastes were in vogue, but such tastes were only available to those who could afford them. Jürgen Kocka, "Bügertum," p. 31.

42 Sheehan, German History, p. 513.
} 
superstructure---the Beamtenstaat, although the majority were by far anything but democrats. ${ }^{43}$

The lower classes in the cities were also undergoing change during the Vormärz. Germany's first large wave of industrialization did not take place until the 1850 s and 60 s, yet it was in this period that the groundwork was prepared for such change. The relatively few industrial workers were primarily technicians, and their economic position was at a higher standard than most unskilled laborers. There were no hordes of impoverished proletarians, but there were definite signs that such a condition would come about. Journeymen artisans were in abundance during the Vormär, and their economic prospects were grim due to the shifting economic system. As with the middle-class, there were regional differences in the condition of the average worker, but porerty and destitution was a real concem because the traditional safety-net of the guild system was disappearing. ${ }^{44}$ As the process of industrialization slowly moved on, many laborers of the Vormärz found that they could not return to the farms. Home-production, the traditional form of manufacture, could not successfully compete with the cheap goods made in the factories, German as well as British and French.

The German nobility, too, underwent some changes during the Vormärw. It still sat at the apex of society--enjoying its hereditary prerogatives,

${ }^{43}$ Tbid., p. 519. 
which had escaped the French Revolution, and compared to the nobility of France and England, it remained more distinctive. ${ }^{45}$ However, to retain its power, the German nobility found itself competing with the emerging middleclass and participating in modem forms of bureaucracy. ${ }^{46}$ Aristocrats found a consolidation of their position by retaining the highest administrative positions in the various bureaucracies of Germany, as well as all of the top military positions. With few exceptions, members of the middle-class were excluded from the ranks of the political elite. ${ }^{47}$ This fostered much resentment throughout the period.

When viewed as a whole, German society in the Vormärz was outwardly static, yet internally unstable. The only thing consistent was change, but not necessarily promoting stability. However, as previously noted, there was no political mechanism extant to facilitate change and absorb new interests into the creation of state policy. Associated with this was a growing discontent within society which played itself out in the culture of the Vormarr. Not everyone, including much of the dynamic bourgeoisie, appreciated or even cared for the new modem aspects of life. German culture during this period evolved in relationship to the advent of modemity.

\footnotetext{
44 Nipperdey, Germany from Napoleon to Bismarck, p. 195.

${ }^{45}$ Kocka, "Bügertum," p. 25.

${ }^{46}$ Sheehan, German History, p. 508.

${ }^{47}$ Nipperdey, Germany from Napoleon to Bismarck, pp. 223-226.
} 


\section{Vormärz Literature}

As noted, the culture of the Vormärz was primarily defined by the middle-class. One of the areas in which the bourgeoisie held the greatest influence was in literature, and it was in that context that the effects of modernization on German society played itself out. Yet German literature during this period was anything but cohesive. It lacked its own aesthetic unity-caught somewhere between Romanticism and Realism. ${ }^{48}$ The literature of the Vormärz either rejected the modern world or it embraced it. In either case, modernity remained the greatest theme.

There were four primary trends in German literature during the Vormär, each with its own particular relationship towards the modern world. The first was actually a hold-over from the last years of the ancien régime. It was embodied by one person--Goethe, who lived from 1749 to 1832 . Indeed it is difficult to speak of Vormärz literature as being its own entity until that year. ${ }^{+9}$ Goethe remained active in literary pursuits up until his death--casting his intellectual shadow upon all other writers of the era. Yet Goethe was a figure from another time--the Kunstepoche--the era of the classic German literature which began in $1770 .^{50} \mathrm{He}$ and the tradition he came from were canonized

\footnotetext{
48 Jost Hermand. "Allgemeine Epochenprobleme," Zur Literatur der Restorationsepoche, 1815-1848, ed. Jost Hermand and Manfred Windfuhr, (Stuttgart: J.B. Metzlersche Verlagsbuchhandlung, 1970), p. 3.

49 Ibid., p. 4.

50 Peter Uwe Hohendahl, Building a National Literature: The Case of Germany, 1830-1870, trans. Renate Franciscono, (Ithaca: Comell University Press, 1989), p. 261.
} 
even before his death by the writers and critics of the Vormär. ${ }^{51}$ As a consequence, he was both revered and criticized--Vormärz writers were forced to find their own place vis-à-vis the classical tradition, but they could never belong to it.

Goethe was notorious for his rejection of the French Revolution. His public stance was neither political or apolitical, it was unattached. Goethe believed in the purity of art as a separate reality from everyday life and most certainly from politics. This detachment brought Goethe much resentment from the younger generation, who demanded a political stance, such as the nationalist critic Wolfgang Menzel (1798-1873). Many members of the activists of the Vormärz chose, by and large, to honor Schiller as their model, for they could see in his writings many modem themes, such as individual freedom. ${ }^{52}$ Schiller too was classified as part of classic German literature, but he was politicized by his admirers. The same could not be done with Goethe.

The second trend in literature during the Vormärz was also of older origin. Romanticism was the greatest social, intellectual, and artistic movement of the first decades of the nineteenth century. German Romanticism evolved and changed throughout the revolutionary era, but it remained, at heart, a

\footnotetext{
51 Eva D. Becker, "Klassiker in der deutschen Literaturgeschichtsschreibung zwischen 1780 und 1860," Zur Literatur der Restorationsepoche, p. 350.

52 Ibid, p. 131.
} 
longing for the infinite and for spiritual harmony. ${ }^{53}$ In many ways, German Romanticism was a reaction to the modern world, in which the socially atomized individual does not know where he stands in relation to God and the universe. ${ }^{54}$ German Romantics during the Vormärz, such as Friedrich Schlegel and his brother, August Wilhelm Schlegel, concluded that the excessive use of reason alienates the individual by breaking down the organic nature of society. ${ }^{55}$ Taking ideas first formulated by Novalis around the turn of century, Frederick Schlegel altered the traditional conception of the Middle Ages as being culturally and artistically quite different from the culture and art of antiquity. ${ }^{56}$ Schlegel believed that German society prior to the Reformation was organic, simple, and harmonious; it was racially pure, heroic, and successful in its synthesis of Roman and German civilization. ${ }^{57}$ Following Schlegel's formulation, German Romanticism during the Vormärz began to focus upon a possible emulation of the harmonious past. Catholicism in particular was looked to by the Romantics as a religion that had once brought unity as well as aesthetic beauty, along the lines of classical antiquity. ${ }^{58}$ Because of its admiration of the past, German Romanticism was, and often still is, classified

\footnotetext{
53 Oskar Walzel, German Romanticism, trans. Alma Lussky, (New York and London: G.P. Putnam's Sons, 1932), p. 20.

${ }^{54}$ Ritchie Robertson, Heine, (New York: Grove Press, 1988), p. 3.

${ }^{55}$ Walzel, German Romanticism, p. 22.

56 Ibid., p. 93.

${ }^{57}$ Ibid., p. 100.
} 
as a conservative and reactionary cultural force. It looked to the Middle Ages as a time of harmony when the church and the state worked together and all the people were united in common beliefs and laws. The forces which culminated in the French Revolution--the Reformation and the Enlightenment--had dissolved the previous state of existence. The Romantics wanted to recapture a mythical past.

The third literary movement of the Vormärz, Biedermeier literature, developed out of a reaction both to Romanticism and to what the middle-class viewed as the negative aspects of the modern world..$^{59}$ Biedermeier writers such as Edmund Mörike (1804-1875) and Karl Immermann (1795-1840) represented the withdrawn, apolitical mindset of many members of German bourgeois society. They were suspicious of liberalism and abhorred the experience of the French Revolution. $^{60}$ They passively accepted the political situation of the Vormärz and concentrated on correcting the loss of community that they perceived as arising from Germany's move towards urbanization and industrialization. Unlike the Romantics, the Biedermeier authors were unconcemed with recapturing man's relationship with the infinite. They were more concemed with family and local society. They suspiciously viewed other authors who did not share their reverence for Heimat (home) and tradition.

\footnotetext{
58 Ibid., p. 98.

59 Nipperdey, Germany from Napoleon to Bismarck, p. 509.

$\infty$ Sagarra, Tradition and Revolution, p. 75.
} 
Many were critics of Goethe due to his uninhibited paganism and cosmopolitanism. ${ }^{61}$ The Biedermeier authors believed in progress through humanistic principles for the individual, who, having been taken away from his natural environment, needed a return to community. They believed that art could serve as a tool for redemption and self-betterment in their dissonant and tumultuous age. ${ }^{62}$

It is not surprising that many of the Biedermeier authors used the Bildungsroman (enlightening/educational novel) to portray the breakdown of society and to propose a reevaluation of contemporary life. The Biedermeier protagonist in such novels starts as a lost soul in a cruel world, but finds happiness in recapturing a sense of community which protects and provides for the individual. Karl Immermann used this theme and idealized Germany's agrarian past in Münchbausen, eine Geschichte in Arabesken, and portrayed the degeneration of the aristocracy and the moral superionity of the middle-class in Die Epogonen. ${ }^{63}$ In his works the true community could only be found or even created by the strong work ethic of the bourgeoisie, who would paternally care for all those of lesser status. Willibald Alexis (Wilhelm Häring, 1798-1871) portrayed communities that prospered due to their resistance to change, such as in Die Hosen des Herm von Bredow. His perfect societies defended tradition

\footnotetext{
61 Nipperdey, Germany from Napoleon to Bismarck, p. 510.

62 Sagarra, Tradition and Revolution, p. 77.

53 Ibid., p. 93.
} 
from the encroachments of the modem world. The Austrian Franz Grillparzer (1791-1872) wrote plays which were blatantly pessimistic about a future in which the community would lose its privileged position to the demands of the individual. In Ein treuer Diener seines Herm and Ein Bruderzwist im Hause Habsburg, Grillparzer presented the state and the church as the moral pillars necessary to ensure prosperity and happiness. ${ }^{64}$ Taken as a whole, the Biedermeier writers never addressed political issues, rather they concentrated on highlighting the dangers of the modem world. Industrialization and secularization meant for them chaos and cultural decline. They dreaded future change. ${ }^{65}$ They thought it possible to find and recreate natural communities in which the enlightened individual could feel safe and at home in the emerging era, despite the changes brought about by the French Revolution. ${ }^{66}$

The fourth literary movement of the era was Junges Deutschland. Like Biedermeier, it was a true Vormärz phenomenon, not a continuation of an older movement. Unlike the Biedermeier writers, the authors of Junges Deutschland staunchly promoted Germany's move into the modern world. They too viewed the condition of German society as intolerable. They saw the problem not in any lack of community, rather in the Vormärz's stagnant and regressive

\footnotetext{
${ }^{64}$ Ibid, p. 96.

65 Ibid., p. 84.

$\infty$ Ibid, p. 79.
} 
social and political climate. ${ }^{67}$ It was after the revolutions of 1830 that Junges Deutschland flourished and writers such as Heinrich Heine (1797-1856) and Ludwig Böme (1786-1837) enjoyed their greatest popularity and notoriety. ${ }^{68}$ They believed that literature could politically and intellectually awaken Germany and create a better future. The writers of Junges Deutschland did not look to the past for their ideal, as did the Romantics and the Biedermeier writers; they looked to the present and to the liberal west. ${ }^{69}$ Just before the time that Karl Marx called for philosophers to participate in changing the world, Ludwig Böme wrote that authors should no longer be Geschichtsschreiber (story writers), but rather Geschichtstreiber (story makers). ${ }^{70}$ The writers of Junges Deutschland were not hostile to the memory of the French Revolution, and they endeavored to make accessible the ideas of modernity which were under attack in Germany. ${ }^{71}$ They advocated an intermixture of politics and art. In 1834, the publicist Ludolph Weinbarg wrote, "The poets and writers of fine prose no longer serve the Muses alone, but the Fatherland; let them be allies in the great causes of

\footnotetext{
${ }^{67}$ Ibid., p. 138.

${ }^{68}$ Heine's inclusion into Junges Deutschland is rather problematic. He always denied membership in any literary movement, however, historians and literary critics have often grouped him with Junges Deutschland because he is considered one of the vanguard members - one of the creators of that style. Also, Heine was labeled a member by the Germanic Confederation in 1835 . In most surveys of German literature Heine is discussed under that heading, yet the label should be taken very loosely.

${ }^{69}$ Jeffrey L. Sammons, Six Essays on the Young German Novel, (Chapel Hill: University of North Carolina Press, 1972), p. 3.

70 Wolfgang Beutin, et al., Deutsche Literaturnescbichte: von den Anfängen bis zur Gegenwart, (Stuttgart: J.B. Metzlersche Verlagsbuchhandlung, 1989), p. 218. The first part of both nouns (Geschichte) can be translated as bistory, as well as story).

71 Sammons, Six Essays, p. 26.
} 
our time." 72 This melding of politics and writing came to be known during the Vormärz as Tendenz--writing with a purpose.

The authors of Junges Deutschland encountered stiff opposition from the powers of the status quo. In 1835, all works written by the "radicals" Gutzkow, Weinbarg, Laube, Mundt, and Heine were banned in Germany because they were "unchristian, blasphemous, and trample underfoot all morality, modesty, and decency." ${ }^{73}$ For his scandalous novel with a liberated female protagonist, Wally, die Zweifelerin, Karl Gutzkow (1811-1878) was imprisoned in $1835^{74}$

Despite their persecution, the opposition writers continued with their endeavors during the 1830 s and 40 s. Without a political voice they had little other choice. "The literary public sphere was the field on which the liberal and democratic opposition could marshal its troops before 1848." ${ }^{75}$ As the political situation became more intense during the $1840 \mathrm{~s}$, so did the opposition writers. The Tendenzdichter (political poets) Georg Herwegh (1817-1875), Ferdinand Freiligrath (1810-1876), and Hoffmann von Fallersleben (1798-1874) characterize the radicalization of Junges Deutschland after 1840. Their poetry reflects the increasing prominence of radical politics along with older demands for national unity. Others, such as Georg Weerth and Adolf Strodtmann,

\footnotetext{
72 Sagarra, Tradition and Revolution, p. 126.

73 Gordon A. Craig, "Heinrich Heine and the Germans," Politics of the Unpolitical: German Writers and the Problem of Power, 1770-1871, (New York: Oxford University Press, 1995), p. 132.

74 Sagarra, Tradition and Revolution, p. 75.

${ }^{75}$ Hohendahl, Building a National Literature, p. 105.
} 
aligned themselves with the cause of early socialism. ${ }^{76}$ Yet, by far, the most famous writer of Junges Deutschland was Heinrich Heine. He differed from the others not only in notoriety, but also in quality. He remains the only Vormärz writer with a European reputation. Although he is most commonly classified as a member of Junges Deutscbland, that is only true to a limited extent. Heine assumed a very independent position from the other opposition writers and never associated himself with one of the developing political parties of the Vormärz: He freely administered criticism to all parties--both Left and Right. Because of this, Heine is deserving of special attention in the context of Vormärz literature and culture. His works provide a wonderful and captivating insight into the essence of the era. Heine was remarkable in that he was not ordinary or typical for his era, but he was definitely a product of it. His evaluations of politics and society come from a unique perspective and consequently illuminate many of the peculiarities of a paradoxical era.

${ }^{76}$ Deutsche Literaturgeschichte, p. 244. 


\section{HEINE: THE SPECTRUM OF VORMÄRZ EXPERIENCE}

An evaluation of Heinrich Heine (bom Harry Heine in 1797) is an excellent vehicle for achieving an understanding of the events and figures of Vormärz Germany. Throughout his life Heine had contact with some of the most influential people and movements of the Vormärz. He was arguably the most famous German writer during the mid-nineteenth century, and at least one later critic labeled him the successor of Goethe. ${ }^{77}$ Besides romantic poetry, for which he attained the greatest fame, Heine wrote widely about politics, culture, and society. His ideas and opinions both reflect and interpret the events and intellectual currents of his time. Yet Heine was also an original thinker who molded contemporary themes into new insights. ${ }^{78}$ He was often accused of being contradictory, but what makes Heine so remarkable as a thinker is not his ideological consistency, but rather his sheer artistic talent. Unlike the majority of his contemporaries, Heine was able to write in a multiplicity of voices, and this is what makes him not only a captivating writer, but also an intriguing historical subject. ${ }^{79}$ Despite its many contradictions,

\footnotetext{
${ }_{77}$ Matthew Amold, Essays in Criticism, First Series, (London: MacMillan and Co., 1865), p. 157.

${ }^{78}$ Jeffery L. Sammons, Heinrich Heine, (Stuttgart: J.B. Metzlersche Verlagsbuchhandlung, 1991), p. 67.

${ }^{79}$ Ibid, p. 275.
} 
Heine's Weltanschauung (world view) embraces a broad spectrum of $V$ ormärz thought and trends. Yet to understand his work, one must understand his complex personality.

\section{Heine the Outsider}

When compared with the majority of his contemporaries, Heinrich Heine is something of an anomaly and is consequently difficult to classify. ${ }^{80}$ His literary endeavors were eclectic: poetry, prose, drama, and joumalism. He was one of the first Germans to make a living from letters alone. ${ }^{81}$ Some of his works, such as the "Lorelei" (poem, 1827) have attained immortal status in the German literary tradition, whereas others, such as his Doktor Faust (ballet, 18+5) are obscure even to those well versed in German literature. As the most popular and influential German writer of his time, he enjoyed an intemational reputation. ${ }^{82}$

Despite his popularity, Heine's position within the German artistic community, both within the borders of Germany and in the exile community of Paris, was that of an outsider. This has usually been attributed to his acerbic personality and propensity to attack his enemies, real and supposed, in his

\footnotetext{
30 Sander Gilman and Peter Hohendahl, "Introduction," Heinrich Heine and the Occident: Multiple Identities, Multiple Receptions, ed. S. Gilman and P. Hohendahl, (Lincoln and London: University of Nebraska Press, 1991), p. 5.

${ }^{81}$ It is necessary to note that the perpetually broke Heine always relied on loans and grants from various sources, most notably his wealthy uncle Solomon Heine in Hamburg.

82 Numerous French intellectuals of the era, such as Theophile Gautier and the Comte de Lautremont praised Heine repeatedly. In England Heine attracted the attention of the critics Matthew Amold and George Elliot.
} 
writings. ${ }^{83}$ He was something of a renegade. Many Germans of the Vormärz viewed his satirical and ironic style as unworthy of a true artist. Some considered it shallow and mean--alien to the "German character of seriousness, honesty, and thoroughness." ${ }^{\text {84 }}$ Heine carefully crafted his style, for he saw satire as the medium most appropriate for his time. As his outsider status grew, his satire and irony became more pronounced, especially in the 1830 s and $40 \mathrm{~s}$ when he and his works were being persecuted in the Confederation. Heine openly acknowledged and accepted this trend. In Die romantiscbe Schule (1836), he wrote:

Writers who suffer under censorship and spiritual oppression and yet cannot renounce their heart-felt opinions are guided towards the form of irony and humor. It is the only resort left to honesty. In the comic-ironic disguise this honesty reveals itself in the most moving fashion. ${ }^{85}$

After his death in 1856, Heine remained an outsider in the tradition of German literature. ${ }^{86}$ This is true for a number of reasons besides his style. First, he was a Jew, and although never religious in any traditional sense and technically a convert to Protestantism, his detractors, especially in the late nineteenth and early twentieth centuries, took great pains to highlight his

\footnotetext{
83 Jeffery L Sammons, Heinrich Heine: A Modem Biography, (Princeton: Princeton University Press, 1979), p. 170.

${ }^{84}$ Jost Hermand, "Heines frühe Kritiker," Der Dichter und seine Zeit, (Heidelberg. Lothar Stiehm Verlag, 1970), p. 124.

${ }^{85}$ Translation--S.S. Prawer, Heine-The Tragic Satirist: $A$ Study of the Later Poety, 1827-1856, Cambridge: Cambridge University Press 1961), p. 106.

${ }^{86}$ Gilman and Hohendahl, "Introduction," p. 7.
} 
Jewishness in order to exclude him from the German national literary canon. ${ }^{87}$ Second, Heine was an unapologetic Francophile. He openly proclaimed France to be the most enlightened nation of Europe because of its revolutionary tradition and liberal political atmosphere after $1830 .^{88}$ As a consequence, German nationalists have often accused him of betraying his homeland ${ }^{89}$ This was of course untrue. Heine remained a patriot of Germany in his own personal manner, even refusing to become a naturalized French citizen. ${ }^{90}$ When it came to the fore in 1848 that he had been receiving a subsidy from the French government, his detractors found new ammunition for their charges. ${ }^{91}$ Third, Heine's close relationship with left-wing intellectuals furthered his outsider status. Regardless of the fact that he did not align himself with any one particular party, and that later in life he professed monarchist principles, Heine's leftist liberal connections made him suspect in the eyes of the German authorities and conservatives. Yet there was never any party in Germany or

\footnotetext{
87 This can be best witnessed in Heinrich von Treitschke's History of Germany in the Nineteenth Century, (London: Jarrold and Sons, 1919) and Richard Wagner's Das Judentum in der Musik, (Weimar. Deutschvölkischer Verlag, 1914). For an excellent example of the extremes which were gone to for this purpose see Steven Fuller's The Napi's Literary Grandfather. Adolf Bartels and Cultural Extremism, 1871-1945, (New York: Peter Lang, 1996).

${ }^{88}$ Sammons, Modern Biography, p. 168.

89 Such accusations increased after the war scare of 1840 .

9 Sammons, Heine, p. 68.

${ }^{91}$ Heine's secret subsidy was for literary purposes and did not prevent him from criticizing the Guizot cabinet. Sammons, Modern Biography, p. 171.
} 
France that could win Heine's permanent allegiance. ${ }^{92}$ Nonetheless, all the factors that made Heine an outsider were used in support of the charge that he was not truly German. ${ }^{93}$

Heine was singled out by the Germanic Confederation as a threat. Labeled a member of Junges Deutschland in 1835, his works were banned because they threatened the proper belief in religion and crown. ${ }^{94}$ Mettemich himself recognized Heine's creative genius, at one point calling him the greatest intellect amongst the opposition writers and, consequently, the greatest danger to the status quo..$^{95}$ By the end of the 1830s, Heine was considered an enemy of the state of Prussia and there were orders to arrest him at the border, should he ever cross it. In the early 1840 s the Prussians also, unsuccessfully, put pressure on the French government to expel him, as they had done with Karl Marx. Such measures drove Heine from any reconciliation with the rulers of Germany. Near the end of the 1830s he felt himself driven in to the camp of the radical opposition, although he never fully embraced that group. ${ }^{96}$ By the early 1840s his radical poems, such as "Lobgesängen auf König Ludwig"(1843) and "Die scblesischen Weber" (1844) placed him firmly in permanent exile--outside.

\footnotetext{
92 Georg Lukács, "Heine und die ideologische Vorbereitung der achtundvierziger Revolution," Aufbau. no.12 (1956), 109-118.

${ }^{93}$ Hermand, "Heine's frühe Kritiker," p. 118.

${ }^{94}$ Nigel Reeves, Heinrich Heine: Poetry and Politics, (Oxford: Oxford University Press, 1974), p. 2

${ }^{25}$ Horst Künzel, "Lyrik als Herrschaftskritik: Zu drei Gedichten Heinrich Heines," Heine Jahrbuch. (1973), 95.

${ }^{96}$ Sammons, Modern Biography, p. 253.
} 
Although Heine was labeled as part of Junges Deutschland, he never shared more than an association of name. In fact, he despised most of the opposition writers of the Vormärz due to their naive politics and meager artistic talent. Even during his radical phase in the early 1840 s he remained critical of the Tendenzdichter, i.e. those poets with a political message. In a poem entitled "Die Tenden₹"(1842), he concludes:

Blase, schmettre, donnre täglich, Bis der letzte Dränger flieht. Singe nur in dieser Richtung, Aber balte deine Dichtung Nur so allgemein als möglich. ${ }^{97}$
Shatter, thunder, night and day Till you've righted every urong! Sing to waken, to incite! But be careful that you write In the vaguest sort of way. ${ }^{98}$

Such off-handed attacks upon the political poets of the left did not win many friends for Heine. He distanced himself from the powers of the status quo, but also from the rising stars of the opposition. ${ }^{99}$ In his scandalous book Ludwig Börne: Eine Denkschrift (1840), he unmercifully attacked the memory of one of the most active and popular republican writers. This led Friedrich Engels to comment that Heine had created a "disgraceful piece of revolver journalism--the worst thing ever written in the German language."100 Engels was to alter his opinion of Heine in the mid 1840s when Marx associated himself with the poet, but he recognized the inconsistencies of Heine's

\footnotetext{
97 "Die Tendeng," Heines Werke, vol. 1 (Berlin und Weimar. Aufbau-Verlag, 1964), p. 153.

98 All translations of Heine's poetry are taken from The Poetry of Heinrich Heine, ed. Frederic Ewen. (Secaucus, NJ: Citadel Press, 1969), unless otherwise noted.

99 Richard Gary Hooten, Heinrich Heine und der Vormärz (Meisenheim am Glan: Verlag Anton Hein, 1978), p. 27.
} 
oppositional stance. After their close association, Marx, too was to criticize Heine, especially after the latter publicly articulated his fears about the Communist movement. ${ }^{101}$

Heine was accused of being many things by his contemporaries. The author Karl Gutzkow called him immoral. ${ }^{102}$ Ludwig Börne accused him of being inconsistent and politically opportunistic to the point of absurdity. "The poor Heine has two backs and he fears the slaps of the aristocrats and the slaps of the republicans. To evade both he must go forward and backward at the same time." ${ }^{103}$

The Bundesversammlung labeled him a direct threat to order and stability. All of these accusations were, to one degree or another, quite true, although Heine himself did not think so. If one focuses on a few major themes, one finds that he was consistent in his inconsistency, although there are a few select elements of his character that one can identify in various periods of his life.

\section{Utopianism}

One of the most important aspects of Heine's personality, evident until late in his life, was his utopian idealism. This element of his character changed and developed as he grew older. It took on different forms and nuances, but it

\footnotetext{
100 Ludwig Marcuse, "Heine and Marx. A History and a Legend," The Germanic Reriew, vol.. 30, no.2 (1955), 114.

101 Ibid., 117.

102 Reeves, Poetry and Politics, p. 81.

103 Sammons, Heine, p. 94.
} 
remained one of the only consistencies of his thought, up until his physical collapse in 1848 . From that point onwards he moved towards an ever greater pessimism, which too was an important feature of his personality. Yet for the period under discussion, the Vormärz, Heine was definitely utopian in his idealism. However, it should be understood that his brand of utopianism was sensual rather than political. Heine's vocabulary was focused around terms of material, emotional, and physical pleasure. For him, these concerns were primary human needs, and politics and economics were only of secondary importance. This hedonism flavored his Weltanschauung and he was consciously aware of this. ${ }^{104}$ His utopia was one of earthly pleasure and it is little wonder that he was attracted to the Saint-Simonian movement in the 1830s. His utopianism also constituted the pith of his criticisms of Germany. He saw the political and social situation of his homeland as stifling progress, as retarding modemity. For Heine, such modernity meant a freeing of the senses as well as a liberalization of the political system. Mettemichian politics and Biedermeier culture strove for neither.

There were many factors that influenced Heine's utopianism and his intellectual development. The first was Romanticism--the tradition in which he was reared. During his boyhood in Düsseldorf, he was exposed to the resurgence of popular folk-songs as published by Achim von Amim (1781-

104 Reeves, Poetry and Poltics, p. 102. 
1831) and Clemens Brentano (1778-1842) as well as the essays of Johann Gottfried Herder (1744-1803). Heine's attitude towards Romanticism was to alter quite considerably later in his life, but he grew up in that tradition, and its influence on him never quite disappeared. Later he lambasted the Romantics for their conservatism, but he continued to see himself as one of them. This was one of his greatest contradictions. As late as the 1840 s he posed as the last true Romantic and he labeled his satire "Atta Troll" (1841) as the last free Romantic poem of the forest. ${ }^{105}$ In the emerging modern world Heine saw a new era of art. He thought it necessary to bring the previous era of Romanticism to a quick end, as it was no longer appropriate. In Die Bäder von Lucca (1829), he wrote of the muses of the old world and the new, and those, as yet undiscovered muses for which he longed. ${ }^{106} \mathrm{He}$ chose not only to become the successor of Romanticism, but also its surmounter. ${ }^{107}$ In a letter to his friend Vamhagen von Ense in 1846, he wrote, "The thousand-year empire of Romanticism is at an end, and I myself was its last and most fabulous king who abdicated the throne."108 In this statement one cannot help but see Heine's connection between Romanticism and the great symbol of the Middle

\footnotetext{
${ }_{105}$ Robertson, Heine, p. 3.

106 "Die Bäder von Lucca," Heines Werke, vol. 3. p. 248.

107 Lucács, "Heine und die ideologische Vorbereitung," 102.

108 Robertson, Heine, p. 3.
} 
Ages--the Holy Roman Empire which was destroyed by the French Revolution and Napoleon.

The first university Heine attended was at Bonn in 1819. It was there he studied under and became personally acquainted with the greatest advocate of the Romantic movement in Germany, August Wilhelm Schlegel (1767-1845). Schlegel aided the young Heine with his first poems, some of which were published in his first major work, Gedichte (1822). Schlegel's lectures on Romanticism centered around an historical perspective that divided the western world into two distinct phases. This was an important stage for the development of Heine's historical/utopian thinking. The first phase that the Romantics recognized was that of classical antiquity, especially ancient Greece. According to Schlegel and the Romantics, the Greek approach to the world was based upon direct observation of reality and mimesis of nature. Consequently, their art and civilization were based on an aesthetic of natural beauty. The second phase of the westem world, for Schlegel, was that of medieval Christianity prior to the Reformation. Its art and culture were based upon transcendental ideals, mysteries, and faith, while retaining the aesthetic of the ancients through the mediation of the Catholic church. The Romantics believed that the world of their time suffered from a paucity of the medieval virtues; it was a period of degeneration. Consequently, the project of the Romantics was to recapture the essence of the medieval world in the form of 
art, so as to help modern man regain his lost relationship with the infinite. ${ }^{109}$ From the 1830 s onwards, Heine criticized this aspect of Romanticism ever more vehemently. He came to recognize the inherent conservatism of Romanticism--it looked backwards and disregarded the achievements of the Enlightenment and the French Revolution. ${ }^{110}$

As a student, Heine aligned himself with the Romantics. He concentrated on medieval love poetry and wrote some imitations of it. He also sought out the organic cultures that still existed in Germany, as they had in the middle ages. In his travel book, Die Harreise (1826) he contrasted the simplicity and harmony of the Harz mountain silver miners with the philistinism of his fellow students; the patriotic Burschenschafter. Following the Romantic precept, Heine wanted to show that it was possible to attain the harmony that had been lost in the modern world, but discovered instead his discomfort with the simple life of the common folk. He realized that he was unable to become part of the organic culture which he sought out. He longed for the past, but his feet were firmly planted in the present. The young Heine saw himself as the epitome of modem man, as zerrissen--caught between the old and new worlds. ${ }^{11}$ He later retumed to this theme in Die Bäder von Lucca by fictitiously explaining that he was born on New Year's Eve 1799 and was

\footnotetext{
109 Reeves, Potry and Politics, p. 12.

110 Lukács, "Heine und der ideologische Vorbereitung," 104.

111 Reeves, Poetry and Politics, p. 21.
} 
therefore the last man of the old century and the first of the new. ${ }^{112}$ As a student these ideas were not yet fully developed, and it would take almost a decade before Heine was to come to terms with his Zerrissenheit.

As Heine developed during the 1820 s, he gradually shifted his focus away form the past towards the possible future. He retained the historical terminology of Schlegel and the Romantics, but he developed a different goal. His utopianism could not be satiated with the unattainable past, but it could look forward to a coming era of harmony and simplicity--an era of freedom. Heine discovered that the beauty of medieval poetry and the folk culture of the Harz silver miners lay in their authenticity--they were true reflections of the experience and time which created them and were not abstract idealism, such as Romanticism. Heine began to think it his duty as an artist to capture the spirit and essence of his age. This, he believed, would heal the introspection of Romanticism and the Zerrissenheit which accompanied the breakthrough into the modern world. Despite recurrent phases of melancholy, he thought that a harmonious society could not be copied from the past, but it could be created for the future. ${ }^{113}$ This modern society, Heine believed, demanded sensual and intellectual freedom. In 1828 he wrote, "All the strength inside the breast of humanity now works towards the love of freedom. Perhaps freedom is the

\footnotetext{
112 "Die Bäder von Lucca."

113 Reeves, Poetry and Politics, p. 35.
} 
religion of the new times." ${ }^{114}$ Heine still continued to write poems such as $I$ ib lieb eine Blume (1828) with the traditional trappings of romantic love-poetry, but new themes appeared in his verse--such as the criticism of censorship, the nobility, and the clergy found in Warnung (1829). Such entities clashed with Heine's conception of true freedom.

Around 1821 Heine moved to the University of Berlin, ostensibly to study law. ${ }^{115}$ At Berlin, he attended some of the lectures of G. W. F. Hegel. Naturally this was a momentous experience, in part because Heine became personally acquainted with the famous philosopher. His relationship to Hegelian philosophy was to change over time, but his familiarity with it was very important in his intellectual development.

Hegelian philosophy, with its emphasis on historical synthesis, was a perfect match for Heine's incomplete ideas of a harmonious future. The teleological conception of history appealed to him, especially with its focus upon ultimate freedom and happiness for it confirmed his utopianism. Heine was able to reevaluate his Romantic predilection for organic cultures. He came to see them as historical manifestations of the World Spirit. Hegel's dialectic also provided a framework in which a synthesis of classical and medieval culture was possible. As a student, Heine was able to combine his Romantic

\footnotetext{
114 "Englische Fragmente," Heines Werke, vol. 3. p. 73. Original translation. 115 Heine had also studied for a short time in Götringen.
} 
disposition with the tradition of German Idealist philosophy. This mixture never left a permanent mark on his view of the world.

Heine's association with the Paris Saint-Simonians in the 1830s further stimulated his conceptions about the modem world and a future utopia. He moved to Paris in 1831 in order to be at the heart of progressive European culture. As early as 1830, in his Englische Fragmente, he describes his admiration of the French as the most enlightened people of Europe.

The French are...the chosen people of the new religion; in their language the first gospels and dogmas are written down; Paris is the new Jerusalem and the Rhine is the Jordan, which separates the land of freedom from the land of the Philistines. ${ }^{116}$

In Paris Heine was immediately attracted to the Saint-Simonian movement, which at that point was under the leadership of the outspoken and enigmatic Prosper Enfantin (1796-1864). The Saint-Simonians wished to create a harmonious society of equals through social planning. He was drawn to the utopian and religious aspects of the movement. ${ }^{117}$ He saw the Saint-Simonians as fighting for the hedonistic liberation of the senses--the emancipation of the flesh. ${ }^{118}$ In explaining his understanding of the aims of the Saint-Simonian movement he wrote,

\footnotetext{
116 "Englishe Fragmente," Translation-Reeves, Poety and Politics, p. 76.

117 Robertson, Heine, p. 38.

118 Reeves, Poetry and Politics, p. 82.
} 
We are not fighting for the right of the people, but for the divine rights of humans. In this, and in many other things, we differ from the men of the revolution. We do not want to be sans-culottes, frugal burghers, cheap presidents; we are founding a democracy of equally magnificent, equally holy, equally blissful gods. You demand simple dress, abstemious habits, and unseasoned pleasures; we, on the other hand, demand nectar and ambrosia, purple cloaks, sumptuous aromas, voluptuousness and luxury, laughing nymph-dance, music and comedies. ${ }^{119}$

Heine never fully understood the economic aspects of Saint-Simonian socialism, although he did recognize the importance of economic relationships throughout history and the impact of industrialization on modern society. ${ }^{120}$ For Heine the prospect of material happiness was the movement's primary attraction. It was a new religion of happiness. ${ }^{121}$ It was during his involvement with the Saint-Simonians that Heine was to write two of his most important analyses of German history and culture: Die romantische Schule and Zur Geschichte der Religion und Pbilosophie in Deutschland (1834). As he began to develop his conceptions about the nature of modernity and a possible future utopia, he recognized that his homeland was far behind in terms of historical progress. He thought it necessary to explain the condition of Germany to the French and also to the Germans themselves.

\footnotetext{
119 Sammons, Heine, p. 66.

120 Sammons, Modern Biography, p. 165. In the 1830s France was much more industrialized than any of the German states.

121 Sammons, Heine, p. 66.
} 
When explaining the trend of romantic literature, popular both in Germany and France, Heine saw two completely different approaches to the same genre. These differences were, for Heine, key to the understanding of what differentiated those lands. For the French Romanticism was merely a literary fad, but for the Germans it was something more.

The writers in Germany who retrieved the Middle Ages from its grave had other purposes, and the effect, which they exercised on the greater population, has endangered the freedom and happiness of my fatherland. French writers had only artistic interests and the French public has only looked to satisfy its growing curiosity. But in Germany it's different--perhaps because the Middle Ages never died and wasted away as in France. ${ }^{122}$

By the 1840s Heine's relationship to the Saint-Simonians had weakened. Besides his discomfort with the leadership of the movement, his ideas about the modem world and the future had shifted. The Saint-Simonians believed that modern society would evolve as they anticipated, and that they, as prophets of the future, would assume control over industry and politics when the time was appropriate. Heine, possibly because he had one eye on the conditions in Germany, took a more radical approach. He saw another revolution as necessary for historical progress. ${ }^{123}$ In that regard Heine returned to his Hegelian roots, but with a closer affinity to the Left-Hegelians, who were coming into their own during this same period. Clarity of thought and action

\footnotetext{
${ }^{122}$ Die Romantische Schule. Original translation.

123 Reeves, Poetry and Politics, p. 110.
} 
were ideas which intrigued Heine during the 1830s. In Zur Geschichte der Religion und Pbilosophie in Deutschland Heine wrote,

Major German philosophers would find my explanations clear and plainly precise, although their own work is profound, immeasurably profound, extremely meaningful, and all the more incoherent. How does a locked granary help the people if they have no key? The people hunger for knowledge and thank me for the small piece of spiritual-bread which I honestly share with them. I don't believe that the majority of leamed men suffer from a lack of talent needed to disseminate ideas about religion and philosophy. I think it is a fear of the results of their own thoughts. ${ }^{24}$

After his experiences with the Saint-Simonians, Heine developed a more skeptical attitude towards utopian movements, although he did not abandon the ideal altogether. In 1844 he met Karl Marx, who was a recent émigré to Paris. Marx too was leery of any brand of socialism which smacked of a cheap utopia. Heine and Marx allied themselves for a brief period, in which Heine wrote his most radical works. However, Heine never gave himself over to the cause of the worker. ${ }^{125}$

In May of 1848 the perpetually ill Heine lost the ability to walk.

Thereafter, he remained bedridden until his death in 1856 . With his deteriorating physical condition and the failures of the revolution outside his windows, Heine's conception of the modern world and his idealism suffered a serious blow. His utopian sentiments gradually succumbed to his pessimism.

124 "Zur Geschichte der Religion und Philosophie in Dextschland" Heines Werke,. vol. 5. p. 14. Original translation. 
Heine shifted from a defender of liberty to a defender of beauty. He

concluded that in a possible world of equals, there was no place for beauty and

genius. ${ }^{126}$ His poetry of the years $1848-1856$ no longer attempts to capture the

essence of the modern world. His poem, Enfant Perdu (1851) sums up his

feelings towards his previous association with the advocates of modemity.

Verlormer Posten in dem Freibeitskriege,

Hielt ich seit dreißig Jabre aus.

Ich kämpfe obne Hoffnung, daß ich siege,

Ich wußte, nie komm ich gesund nach Haus.

Ich wachte Tag und Nacht - Ich konnt nicht scblafen.

Wie in dem Lagerzelt der Freunde Schar -

(Auch bielt das laute Schnarchen dieser Braven

Mich wach, wenn ich ein bißchen schlummrig war).

In jenen Nächten bat Langweil ergriffen

Mich oft, auch Furcht - (nur Narren fürbten nichts)

Sie zu verscheuchen, hab ich dann gepfiffen

Die frechen Reime eines Spottgedichts.

Ja, wachsam stand ich, das Gewebr im Arme,

Und nabte ingindein verdächt'ger Gauch,

So schoß ich gut und jagt ibm eine warme,

Brübuarme Kugel in den schnöden Bauch.

Mitunter freilich mocht es sich ereignen, Daß solch ein scblechter Gauch gleichfalls sebr gut

Zu schießen wußte - ach, ich kann's nicht leugnen -

Die Wunden klaffen - es verströmt mein Blut.

Ein Posten ist vakant! - Die Wunden klaffen -

Der eine fällt, die andern rücken nach -

Doch fall ich unbesiegt, und meine Waffen

Sind nicht gebrochen - Nur mein Herze brach. ${ }^{127}$
For thirty years I've clung without retreat To bopeless posts on Freedom's battleground; I fought within the shadows of defeat;

I knew I'd never come bome saffe and sound.

Day and night I waked - I could not sleep Like all my bands of comrades in their tents; (And when I tried to doze, these braves would keep Me wakeful - snoring with such violence.)

Boredom would seize me often in those nights, And fear - (only fools are spared that curse); To banish these and set myself to rights, I'd whistle a satire's saucy little verse.

Yes, gun on arm I watched, and when some clown Suspiciously approached, I'd send a sbot, A well-aimed little bullet, burtling down Into bis evil belly - scalding hot.

Sometimes, of course, it may have come to pass That such an evil clown was just about As good a shot as I - it's true, alas -

My wounds are open - and my blood runs out.

A post is vacant! - all my wounds are open One soldier falls; another fills his part -

But unsubdued I fall my weapon not broken. The only thing that's broken is my heart.

\footnotetext{
125 Marcuse, "Heine and Marx," 112.

${ }^{126}$ Sammons, Modern Biography, p. 239.

127 "Enfant Perchu," Heines Werke, vol.1, p.290.
} 


\section{Goethe the Genius and the Purpose of Art in the Modern World}

It is impossible to separate Heine's conceptions about the modem world from his ideas about the nature and purpose of art. In his thought they are intertwined. As with most other aspects of his Weltanschauung, his conception of the ultimate purpose of art subtly changed and shifted from one stage of his life to the next. Yet his most basic views can be ascertained by an examination of his attitude towards Germany's greatest literary figure--Goethe.

Heine's attitude towards Goethe was always somewhat schizophrenic. He often praised and criticized Goethe in the same breath. Heine's detractors found this most irksome. Böme, a critic of both Goethe and Heine, found this to be one of his greatest faults. ${ }^{128}$ Heine was always careful to separate Goethe's artistic qualities from his opinions of the man, for the simple fact that he always admired Goethe's poetic ability. ${ }^{129}$ It should be remembered that during the Vormärz all of the German writers had to react to the overpowering presence of Goethe. Heine was no exception. In the early 1820 s and 30 s he shared the view of most of his contemporaries that Goethe was no longer attached to his own time; that he was a relic from a former age. Using Hegelian terms, Heine classified artists according to their Zeitgemäßheit (timeliness), that is, the extent to which they conformed to the latest manifestation of the World Spirit. Heine believed, as did all the writers of

\footnotetext{
128 Sammons, Modern Biography, p. 239.
} 
Junges Deutscbland, that Goethe did not possess the Idee (idea, spirit) of the modern world. He remained a figure from the Kunstepoche, living anachronistically in the modem world. ${ }^{130}$ Heine believed that modernity demanded committed literature, working towards the realization of freedom.

Unlike the critics Wolfgang Menzel and Ludwig Börne, Heine could not completely dismiss Goethe. The beauty and authority of Goethe's works were, for Heine, too important to be ignored. Goethe may not have been a modern artist as Heine conceived one should be, but he was still a genius. Heine saw Goethe as standing above the Entrzveiung (the dissonance) of the Christian age. He was, for Heine, the universal genius, the pure aesthete. ${ }^{131}$ Heine could relate to this definition, for he too was an aesthete. Böme had criticized Heine as loving the truth only when it was beautiful. ${ }^{132}$ This jab was not far off the mark. Heine had leveled the same criticism at Goethe, whom he had briefly met in 1824. He believed that Goethe's works "adom our dear country as statues adom a garden, but they are statues. On can fall in love with them, but they are sterile." ${ }^{\prime 133}$ As an alternative to Goethe, Heine looked to Jean Paul (1763-1825) as a model of the engaged artist. Heine saw almost religious qualities in any artist who tackled the issues of his day, and he lambasted the

\footnotetext{
129 Reeves, Poetry and Politics, p. 56.

130 Ibid, p. 93.

131 Ibid, p. 145.

132 Ibid., p. 167.
} 
Biedermeier writers, such as Gustav Schwab (1792-1850) for their domesticity and irrelevance. ${ }^{134}$ This dichotomy of engaged art versus pure art was one which remained with Heine throughout his life. He believed that the modem world demanded literary engagement, but he held on to the nobility of the Kunstepoche as well as his Romantic roots.

This problem of engaged art was to preoccupy Heine during the L'ormär: He dismissed the Biedermeier writers, such as August von Platen, as uncommitted and unzeitgemä $\beta$, and at the same time he lambasted the Tendezdichter of Junges Deutschland, such as Freiligrath and Herwegh, because of their poor artistic quality. Heine believed that the true democrat writes like the people, sincerely, simply, and badly. ${ }^{135}$ In literary matters his measuring stick was aesthetic, not political. He shared the same enemies with the Tenden dichter, but he could not join forces with them because they were boorish philistines who cloaked their creative limitations in popular thetoric. Heine felt that he was surrounded on all sides by men of limited intellect who did not understand that the modern world needed emancipatory art, but that such art needed also to be true art. He believed that only he could supply such a commodity.

\footnotetext{
133 Robertson, Heine, p. 2.

134 Sammons, Heine, p. 90.

135 Reeves, Poetry and Politics, p. 218.
} 


\section{Nazarenism vs. Hellenism}

Another part of Heine's Weltanschauung affected his conception of modernity--his ideas about religion in world history. This element was an inseparable component of his aesthetic and political idealism. Following the logic of Hegel's dialectic, Heine formulated a view of the evolution of westem religion with two polar opposites--the thesis and antithesis. Heine attained his ideas about these opposite religious approaches to the world during his time with Schlegel and his involvement with Romanticism. The two religious outlooks, or ideals, were spiritualism and sensualism, which Heine later termed Nazarenism and Hellenism. Heine believed that these antithetical religious views had clashed throughout history, and that in the modern world they would synthesize into a new religion of purity and strength.

Heine defined Nazarenism as the westem religious tradition which originated in Judaism and later became the root of Christianity. It was a religion that emphasized the dominance of the spirit over the senses and the physical body. It subjugated all earthly endeavors to a higher goal. Art and philosophy, as well as other aspects of human culture, were used only as receptacles for transcendental truths. Hellenism, as exemplified by the pagan religion of the Greeks, elevated the natural and physical world to an exalted position. Heine believed that the western world had, for too long, suffered under the yoke of spiritualist repression and that a movement to incorporate 
sensualism was necessary for human progression. ${ }^{136}$ The French Revolution had started the transformation, but the overthrow of the tyranny of Nazarenism was not yet complete. Heine believed that sensual freedom was the new religion of the modern world. ${ }^{137}$ He believed that the spreading of the new gospel was the true object and goal of modem literature.

Heine did not want to unbalance the dichotomy of sensualism and spiritualism toward the materialistic side. Rather he wanted to recover a balance, to vindicate the rights of the senses "without denying the rights of the spirit, not even the supremacy of the spirit." But he did want to show how in society religious repressiveness was associated with political repression, the alliance of throne and altar that denied to the majority its aspirations to the goods of this world and offered feeble compensation with the promise of "pie in the sky when you die." For Heine spiritualist repression was not symptomatic of political repression, but its central feature. ${ }^{138}$

Heine often attacked his enemies on base and personal levels, but he also cloaked his opinions with terminology that he developed from his religious views. When Heine struck out against the recently deceased Böme in 1840 , he argued that the radical republican was no more than just a modern-day Puritan. According to Heine, Böme had worked not to overthrow oppression and institute freedom, but to exchange one form of oppression for another. His political radicalism was only a manifestation of intolerance. He had not concerned himself with freeing the senses, which Heine believed was the

\footnotetext{
136 Robertson, Heine, p. 42.

137 Sammons, Modern Biography, p. 150.

138 Ibid., p. 148.
} 
starting point for political emancipation. Heine thought that all the republicans of his day were steeped in intolerance and purposefully ignored the sensual needs of society. ${ }^{139}$

Heine's ideas about religion, Nazarenism and Hellenism, remained with him until his death, although he lost faith in any synthesis of the two polar opposites in the early 1850s. In his poem, "Für die Mouche," written one month before his death in 1856 , Heine used the symbols of these religions, but there is no resolution, no synthesis, only continual strife.

\author{
Spukt in dem Stein der alte Glaubenswahn? \\ Und disputieren diese Marmorschemen? \\ Der Schreckensruf des wilden $W$ aldgotts $P$ an \\ Wetteifernd wild mit Mosis Anathemen! \\ Oh, dieser Streit wird enden nimmermebr, \\ Stets uird die Wabrbeit hadern mit dem Schönen, \\ Stets wird geschieden sein der Menschbeit Heer \\ In zwei Partein: Barbaren und Hellenen. ${ }^{140}$
}

Does superstition haunt the stones once more? And are these marble phantoms locked in war? Pan, the savage god of the forest, throws bis Terror-cry against the curse of Moses.

$O$ there will never be an end to this;

Beauty and truth can reach no armistice;

The Legion of bumanity must sever.

Barbarians and Greeks, opposed forever.

\section{Napoleon and Revolution}

As noted, up until 1848 Heine viewed history as a Hegelian. He believed that there was a teleological process which could both be understood and evaluated. The ultimate Hegelian synthesis that be reached when spirit and matter united, and an era of freedom and harmony would ensue. Accordingly, Heine classified all worldly phenomena with this in mind. He evaluated people,

\footnotetext{
139 Ibid, p. 239. It is interesting that Thomas Mann's favorite work of Heine's was the Böme book that was so unpopular in its day, and marks the low point of Heine's career and his final estrangement from the liberal left in Germany. Thomas Mann, "Notiz über Heine," Reden und Aufsätze, vol.. 10 (Oldenburg: S. Fischer Verlag, 1960), p. 839.
}

140 "Für die Mouche," Heines Werke, vol. 1. pp. 440-445. 
actions, and ideas by their worth and relationship to the progressive evolution of history, and he criticized the institutions which he believed to be relics of the past, with no connection to the spirit of the time. As he moved in a leftHegelian direction in the late 1830 s and early 40 s, he began to consider the necessity of revolution for the purpose of tearing down the obstacles to progression, such as the outdated institutions of state. ${ }^{1+1}$ Heine once remarked that in Berlin Hegel had casually told him his revised dictum, "what was rational sbould be real." This was the great Schulgeheimnis (school secret) of his youth. ${ }^{142}$ Such thinking demanded action. This train of thought compelled Heine to move away from the ineffectual Saint-Simonians and to develop a more radical approach. He believed that Germany could not enter into the modem world unless action was taken.

Heine's views on revolution were not necessarily new circa 1840 . As a child, he had had first-hand experience with the French Revolution growing up in French-occupied Düsseldorf. As a Jew, he appreciated the liberal atmosphere and emancipation process begun by the French. He claimed to have even seen Napoleon ride through his home town, and it was that experience which he believed made him understand the French Revolution better than anything else. As an adult, Heine came to see Napoleon as the

\footnotetext{
${ }^{141}$ Künzel, "Lyrik als Herrschaftskritik," 84.

142 Waltex Grab, Heinrich Heine als politischer Dichter, (Heidelberg: Büchergilde Gutenberg, 1982), p. 41.
} 
physical manifestation of the French Revolution: the Hegelian world spirit on horseback. ${ }^{143}$

The figure of Napoleon as the vanguard of the French Revolution and modemity was to play an important part in Heine's thought. As he had done with Goethe, Heine saw Napoleon as more than a mere mortal. Both were figures that transcended their world through the power of clear perception. ${ }^{1+4}$ They differed in that Goethe represented the nobility and beauty of the old world, while Napoleon characterized the coming freedom of the new.

What Heine riewed as progressive and therefore good in the French Revolution and Napoleon, he saw destroyed in their antithesis--the Restoration and Romanticism. Reactionary politics and conservative idealism destroyed progression and hindered the new era of promise. The specific enemies of progress in Germany that Heine identified were: the aristocracy, the clergy, and the cultural philistines. Heine believed that it was these power-interests that not only had defeated Napoleon but also kept Germany in the past. ${ }^{145}$

The aristocracy and the clergy were, for Heine, holdovers from the Middle Ages. Napoleon had been unsuccessful in ousting them from power in Germany, and they were the forces that triumphed at the Congress of Vienna. Among other things, they were responsible for the reinstitution of state

\footnotetext{
${ }^{143}$ Lukács, "Heine und die ideologische Vorbereitung," 171.

144 Reeves, Poetry and Politics, p. 29.

145 Ibid., p. 25.
} 
oppression of Jews in Germany. They were the forces that kept new interests from attaining any political voice. The cultural philistines were the members of the gullible middle-class who betrayed the Revolution and Napoleon for promises of nationhood and wealth. ${ }^{146}$ While they attained the second of those two goals, they were duped by the powers of the status quo. They generally misunderstood the changes in the world around them and were consequently ineffectual in their desire for nationhood. They forgot their original desire for freedom as well as for unity, and came to rely upon change from above, which never came.

Heine viewed the situation in Germany as backwards and medieval. The forces in power, allied with conservative groups, were unwilling to change. The elements in society that desired change were either chauvinistic (the nationalists) or ineffectual (the liberals and republicans). In Heine's opinion, none of these groups fully understood the significance of Napoleon and the French Revolution. Each pursued aims that kept Germany stagnant and well behind its western neighbor.

\section{German Pantheism and German Philosophy}

By the mid 1830s Heine had developed one of his most original ideas, which was to exert itself in his Weltanschauung, his conception of modernity, and his subsequent critique of Vormärz Germany. Although this idea cannot be

\footnotetext{
146 Craig, The Politics of the Unpolitical, p. 137.
} 
labeled a philosophy, Heine did feel that, in terms of importance to the world, his discovery would be earth shattering. What Heine found was that upon a close investigation of history, literature, religion, and philosophy, the German people bore within their national psyche the seeds of violent revolution. Heine incorporated many aspects of his previous thought into this concept which he believed centered around two key elements--the rebirth of German pantheism and the terrible logic of German Idealism.

The clearest explanation of the concept is found in Zur Geschichte der Religion und Philosophie in Deutschland. In that work Heine explains that there is a secret religion, which, in the developing new world, would soon rear its terrible head. ${ }^{147}$ This religion was the pantheistic religion of the ancient Germans, which had been conquered by Christianity but never totally destroyed. The ancient Germanic religion of nature transformed itself into legends of folkculture--forest nymphs, cave dwelling kobolds, etc. These demi-gods survived in folk-stories throughout the Middle Ages, despite the efforts of the clergy to suppress them. Heine, true to his Romantic roots, believed that the Germans never ended their belief in such figures. They merely renamed them demons and spirits, in accordance with the demands of the church. The folk stories collected by the Brothers Grimm and Amim and Brentano provided numerous examples of this secret religion. Heine believed a revival of this religion would

${ }_{147}$ Zur Geschichte der Religion und Philosophie in Deutschland, p. 8. 
come about because the logic of German Idealist philosophy had shown once and for all the impossibility of ever proving the existence of the Christian God, even though since the time of Martin Luther religion had come to rely upon logic in defense of its tenants. ${ }^{148}$ Starting with Kant, who had originally concluded that God was unprovable in the Critique of Pure Reason (1781), but later recanted in Critique of Practical Reason (1788) once he truly recognized the agnostic implications of his ideas, Heine stated that the Germans had begun the intellectual and spiritual equivalent of the French Revolution. Robespierre had killed the king, Kant had killed God. ${ }^{149}$ The logic of Hegel was the terminus of this "German Revolution." Heine thought that once the implications of Idealist philosophy were truly understood, the masses would lose their faith in God and revert to the worship of nature--their original religion.

Thought precedes action like lightning thunder. The German thunder is of course a German, and is very supple, and rolls somewhat slowly along, but it will come, and when it is heard, as it has never before been heard in the world, it will be known that the German thunder has finally reached its goal. The old stone gods will raise themselves from the ruins and wipe the thousand-year-old dust from their eyes, and Thor with his giant hammer will jump into the air and smash the gothic cathedrals. ${ }^{150}$

\footnotetext{
148 Robertson, Heine, p. 44.

${ }^{149}$ Künzel, "Lyrik als Herrschaftskritik," 85.

150 Zur Geschichte. p. 141. Original translation.
} 
In addition to the overwhelming force of German philosophy, Heine believed that the Christian God is out of place, and therefore, inconsequent in the modem world. He has become the antithesis of himself--from terrible harbinger of wrath to pitiful figure of contempt, who could no longer exert his right to dominance over the gods of nature. Heine believed the transformation was close at hand.

We saw how he became yet more spiritual, how he whimpered mildly, how he became a loving father, a friend of mankind, a universal benefactor, a philanthropist--none of it helped him-Do you hear the bell ringing? Kneel down--they are bringing the sacraments to a dying God. ${ }^{151}$

Heine believed that Spinoza had anticipated this conclusion and that Schelling had disseminated it to the Romantics--with the conception of God and nature as one and the same. ${ }^{152}$ Once the two parallel lines of pantheism and idealism merged, Christianity would be assailed and suppressed by the religion it had once vanquished. For Heine, this was the real revolution necessary for historical progression and earthly happiness--the destruction of the nazarene religion that buttressed the powers of the still existent ancien régime. ${ }^{153}$

\footnotetext{
151 Ibid., p. 92. Original translation.

152 Robertson, Heine, p. 45.

153 Zur Geschichte der Religion und Philosophie in Deutschland, p. 15.
} 


\section{Heine and the Vormärz}

Besides Heine's grander ideas about history, religion, and philosophy, there existed another element to his character and writings. From the early 1830 s to the late 1840 s he was very much concerned with and involved in the issues of his day. His writings, especially the feuilleton style newspaper articles, are filled with direct and indirect comments about the state of affairs in Germany, France, and Europe. His politics were always unclear and uncommitted, but this aloofness gave him the freedom to criticize all parties. The clearest picture of Heine during the Vormär is one of a committed defender of freedom, both politically and sensually. In that regard, he resembled a left-liberal. However, he always retained the Romantic notion of the nobility of intellect and talent, which often clashed with the ideas of the more radical leftists. He was indeed a very enigmatic figure. He does not easily fit into any label or grouping. Consequently, his critique of L'ormär Germany is multifaceted and often appears contradictory. Heine did not possess the consistency of an ideologue, but he did have the gift of insight as well as the talent to give such insight captivating expression. He was a product of his age-an inheritor of the Enlightenment and the French Revolution. In following with the Hegelian vogue of the Vormäry, Heine looked for synthesis and teleology--he looked for positive historical progression. However, he did not find what he wished to see. The blatant contradictions of his age, the political 
restoration, and the conservatism of many of his contemporaries struck Heine as absurd. It is not surprising that a man such as Heine was so fond of satire, for him no other form of literary expression could have described the Vormärz better. 
Chapter 4

\section{DEUTSCHLAND: EIN WINTERMÄRCHEN}

Heine's most famous and arguably greatest satire of the Vormärz is his epic poem Deutschland: Ein Wintermärchen. It provides one of the best examples of his wit and untiring propaganda for the principle of 1789 as well as his broader views on the nature of the modern world and the role of the modem artist. It is a work in which Heine sets himself up as the critic of all the elements which he dislikes in his homeland, posing as the modem critic traveling into the land of the past. He is the francophile, the lost Romantic, the only true poet of his time. He is the opposition to everything, including the opposition.

\section{The Composition of Deutschland: Ein Wintermärchen}

Heine began Deutschland: Ein Wintermärchen in January of 1844, at the age of forty-seven. It is ostensibly a fictionalized travel record of his first return trip to Germany after thirteen years of self-imposed then, de facto exile in France. Preceding in reverse order from his actual voyage in the late autumn of 1843 , Heine used the form of the mock-epic to record his observations and opinions of contemporary conditions in Germany. Besides the travel account, Heine used numerous romantic dream sequences throughout the poem to 
illustrate his points and ideas. Deutschland appeared in installments in the radical Paris joumal Vorwärts! in October and November of 1844. It was published in Germany in September as part of Heine's collection of poems entitled Neue Gedichte by his publisher, Hoffmann and Campe, in Hamburg. ${ }^{154}$

In writing Deutschland: Ein Wintermärchen Heine strove to outdo the German Tendenzdichter (political writers) of the early 1840s, such as Freiligrath, Herwegh, and Hoffmann von Fallersleben. These authors Heine satirized in Atta Troll, which was also written in the same period. ${ }^{155}$ Yet Heine felt he needed to do much more. It was in this period that Hoffmann von Fallersleben wrote Deutschland, Deutschland ïber alles. Heine could see that the liberal opposition was entering into an ugly relationship with chauvinistic German nationalism. He used Deutschland: Ein Wintermärchen as a weapon to both ridicule the Tendenzdichter and also to steal their thunder by creating a work that overshadowed their "aesthetically unnecessary beer-hall poetry." He also used it to present what he believed to be the true calling of modernity which

\footnotetext{
154 To oversee the successful publication of Deutschland and to finish uncompleted family business Heine retumed for his second and final trip to Germany. The second voyage was undertaken entirely by ship and did not result in any literary creation.

155 Jeffrey Sammons has argued that Atta Troll: Ein Sommernachtstraum and Deutschland: Ein Wintermörchen are two poems which must be viewed together. Indeed both poems (with obvious Shakespeareinfluenced titles) deal with the Vormärz phenomenon of political activism and cultural philistinism. For the purposes of this study only Deutschland will be discussed because for the contemporary reader the illusions and double-entendres of $A$ tta Trall are much too obscure and a competent analysis of that work would entail a much broader and longer research paper. It is necessary to explain that the creation of Atta Troll took place from 1843 to 1847, enveloping the creation of Deutschland. Sammons, Heine, p. 109.
} 
they could not see. ${ }^{156}$ A second reason for writing Deutschland: Ein Wintermärchen was to respond to the increased pressure Heine felt from the Confederation and specific states, i.e. Prussia. In many ways, he felt himself being driven away from any reconciliation with the ruling powers of Germany and into the arms of the demagogues, whom he had previously driven away with his polemics. Yet this was only true to a limited degree. Heine realized that he shared enemies with the Tendenzdichter, but he could not bring himself to like them. Consequently, he used Deutschland: Ein Wintermärchen to fight on two fronts. Striking back against the powers of the status quo in Germany and lampooning the ineffectual Tendenzdichter. He believed that the ruling powers hindered the promise of the modem world and that the political poets made a mockery of it. ${ }^{157}$ Heine felt that only he could bring Germany into the modern world, although such action would not come without sacrifice. In the foreword to Deutschland: Ein Wintermärchen he qualifies his vision to those he knew would accuse him of being a traitor.

\footnotetext{
${ }^{156}$ Jeffrey L. Sammons, Heinrich Heine, p. 102.

157 Ibid., p. 102.
} 
I already hear your beer voices: "You blaspheme our colors, betrayer of the Fatherland, friend of the French, to whom you want to give away the free Rhine." Calm yourselves. I will honor and respect your colors when they earn it, when they are no longer useless and subservient playthings. Plant the blackred-gold on the heights of German thought, make it into the standard of free humanity, and I will give my heart's blood for it. Calm yourselves, I love the Fatherland as much as you. Because of this love I have spent thirteen years in exile, and also because of this love I return into exile, possibly forever, without tears or sour expression. ${ }^{158}$

In the early 1840 s Heine was in a period of isolation. It was probably the lowest point in his career as a writer, although he returned to the Augsburger Allgemeine Zeitung as a Paris correspondent. He was so aloof that in 1842 Friedrich Engels remarked on possible apostasy. ${ }^{159}$ It was during this period that Heine met and befriended Karl Marx, who had recently been expelled from Germany. Many scholars have argued that Marx deeply influenced Heine. ${ }^{160}$ Such an influence is difficult to document, yet it remains feasible; for it is in this period that Heine's works display a new and more politically radical emphasis than is evident in his earlier productions. ${ }^{161}$ During his association with Marx, Heine wrote around thirty overtly political poems which he labeled as Zeitgedichte (poems of the time). Many of these poems were published by Marx in Vorwärts!, in part because Heine's publisher in Germany, Campe,

\footnotetext{
158 "Deutschland: Ein Wintermärchen," Heines Werke, vol 2. p. 92. Original translation.

159 Marcuse, "Heine and Marx," 110.

160 Ibid., p. 118.

161 Grab, Heine als politischer Dichter, p. 90.
} 
declined to distribute material he knew would immediately bring the wrath of the German censors down upon his firm. ${ }^{162}$ The tone of Heine's Zeitgedichte, such as "Die schlesischen Weber" with its three-fold curse upon God, king, and fatherland, were uncharacteristically radical for him. His subtle irony was replaced by more overt challenges and threats as well as an overriding negativity. ${ }^{163}$ Perhaps this is due to Heine's deeply felt fears about a possible communist future. ${ }^{164}$ Heine always differed from Marx in that his vision of the future was a meritocracy in which a nobility of creativity and intellect would flourish, possibly under some form of constitutional monarchy. ${ }^{165} \mathrm{He}$ feared the rule of the mob, although the logic of Marx's arguments persuaded him that the future would probably belong to the workers. In his preface to the French edition of Lutetia, a collection of newspaper articles written in the 1840 s, published in 1854, Heine articulated the fears that he first developed during his association with Marx.

\footnotetext{
162 All works by Hoffmann and Campe were banned in Prussia in 1842. The ban was lifted during the reconstruction of Hamburg after its great fire of 1843 . Reeves, Poetry and Politics, p. 152.

163 Sammons, Heine, p. 103.

${ }^{164}$ Robertson, Heine, p. 70.

165 Ibid, p. 57.
} 
It is only with fear and horror that I think of the epoch in which these gloomy iconoclasts will seize power; with their callused hands they will pitilessly smash all the marble statues of beauty which are so dear to my heart; they will shatter all that fantastic frill-work and glitter of art the poet loved so much; they will fell my laurel groves and plant potatoes in their stead; the lilies which neither spun nor worked, but were dressed with the splendor of Solomon, will be tom from the soil of society, if they refuse to turn their hands to the spindle; the roses, idle brides of the nightingales, those useless singers, will be chased away, and alas! My Buch der Lieder will serve the grocer as paper cones in which to pour coffee or snuff for the old ladies of the future. Oh! I can see all of this beforehand, and an unutterable sadness steals over me when I think of the ruin with which the victorious proletariat threatens my verse. For this will sink into the grave with all the rest of the Romantic world. ${ }^{166}$

Heine's fears about the future were less developed at the point when he wrote Deutschland: Ein Wintermärchen, and Marx's connection to radical newspapers, in which both he and Heine published, provided Heine with a forum where he could write with venom. Marx may not have won Heine over with his theories, but the intensity of the poet's endeavor was noticeably more pronounced during their brief association. ${ }^{167}$ Where Heine and Marx differed was in terms of commitment. After the catastrophe of 1848, Marx maintained his radical opposition, whereas Heine withdrew from activism. In Deutschland: Ein Wintermärchen, Heine's curiously dichotomous position can be noticed. His change after 1848 seems less of a surprise if one recognizes some of these tensions in the poem.

${ }^{266}$ Marcuse, "Teine and Marx," 121. 
In terms of formal structure, Deutschland is divided into twenty-seren capita, or chapters, written in a traditional folk style of rhyme. It is a romantic satire of Romanticism in which Heine presents Germany as a backward land, asleep in winter hibernation; it has failed to see the springtime of the French Revolution, and as a consequence, it has failed to enter into the modem world. ${ }^{168}$ This simple criticism is what makes up the core of Deutschland. There are many different and particular aspects that Heine chooses to focus on with his critique, but the emphasis is always on Germany's inability or unwillingness to accept that the world has changed and left it behind. But Heine's personal duality--his association with Germany's history and its cultural traditions, i.e. Romanticism, provide an intriguing perspective. He acknowledges the present, but he feels that he too belongs to the past. Deutschland is at once a critique of Germany and also an effort in self-realization for the zerrissen poet.

\section{Medieval vs. Modern}

Deutschland simply begins with Heine crossing the border, yet this act of crossing is more than just literal. Going into Germany is, for Heine, returning to the past, to the romantic land of fairy-tales, to the Middle Ages. The later dream-sequences of the poem come as a necessary part of such an environment. It is fitting that Heine's first image in Deutschland is that of the harp-maiden at the border who sings romantic love-songs with great feeling,

167 Ibid., 118. 
yet with a false tone, or voice, which immediately affects the homesick traveler. She is a Lorelei-irresistible danger. Figuratively, at the border Heine leaves modem, progressive France and enters in to medieval Germany, a land which at once is seductive, but also deadly for the Romantic poet. At the beginning of the poem Heine declares his opposition and immediately sets himself apart from this idyllic scene and announces his progressive idealism--his optimism for the future. ${ }^{169}$ He believes that the old songs of Germany must go and that a new era must be ushered in.

Ein neues Lied, ein besseres Lied,

O Freunde will ich euch dichten!

Wir wollen hier auf Erden schon

Das Himmelreich errichten.

Wir wollen auf Erden glücklich sein, Und wollen nicht mehr darben; $V$ erschlemmen soll nicht der faule Bauch, Was fleißige Hände erwarben.

Es wächst bienieden Brot genug

Für alle Menschenkinder,

Auch Rosen und Myrten, Schönbeit und Lust,

Und Zuckererbsen nicht minder.

Ja, Zuckererbsen für jedermann,

Sobald die Schoten platzen!

Den Himmel überlassen wir

Den Engeln und den Spatzen. ${ }^{170}$
$A$ new song, and a better song,

Ob friends, I'll urite for you.

Here on earth we mean to make

Our beaven come true.

We mean to be happy here on earth, Our doys of want are done.

No more shall the lavy belly waste,

What toiling hands have won.

Bread enough for all mankind, Is planted here below;

Roses and myrtle, beauty and joy, And sweet-peas, row upon row.

Yes, sweet-peas enough for every man, As soon as they break their pods! We gladly leave to the angels and birds The heaven of the gods.

Heine qualifies this grand statement by announcing to Germany that in the modem world the maiden Europe is engaged to be married with Freedom He says that despite the lack of religious sanction, the marriage of the two will

\footnotetext{
168 Grab, Heine als poltischer Dichter, p. 90.

169 Ibid., p. 93.
} 
nonetheless be valid and their children will enjoy a life of harmony and material happiness. ${ }^{171}$ Heine presents himself as the harbinger of this modernity - the new poet for the new times. He comes as an opponent of the status quo. No matter how diligently the powers of reaction work to silence him, they cannot succeed. He carries the powerful ideas of modemity in his mind, which they cannot see. When his bags are searched at the border he declares:

Ihr Toren, die ibr im Koffer sucht!

Hier werdet ibr nichts entdecken!

Die Konterbande, die mit mir reist,

Die hab ich im Kopfe stecken.

Hier bab ich Spitzen, die feiner sind Als die von Brüssel und Melcheln, Und pack ich einst meine Spitzen aus, Sie werden euch sticheln und becheln.

Im Kopfe trage ich Bijouterien,

Der Zukunft Krondiamanten,

Die Tempelkleinodien des neuen Gotts,

Des großen Unbekannten.

Und viele Bücher trag ich im Kopf?

Ich darf es euch versichern,

Mein Kopf ist ein zuitscherndes Vogelnest

$V$ on konfiszierlichen Bücher. ${ }^{172}$
You fools search inside my trunk!

Here's notbing that you can find.

The contraband that journeys with me,

I've stuck inside my mind.

I'ie lace that that the laces of Mecklenburg And Brussels can bardly match.

Just wait till my needle-points are unpacked, You'll feel them prick and scratch.

The future's bright cronn-diamonds

Are glittering in me,

The temple-gems of the great unknown,

The god that is to be.

And I carry many books in my bead!

Solemnly I state it

My bead is a bird-nest twittering

With books to be confiscated.

Heine feels that the period of the Middle Ages must be shown for what it really was--a time of repression, ignorance, and lack of freedom.

romanticism remains, for Heine, the tie that keeps Germany bound to the past. ${ }^{173}$ He sees the repressive thrust of Romanticism all around him, and this

\footnotetext{
170 “Deutschland" p. 95.

171 Ibid, p. 96.

172 Ibid., p. 97.

173 Sammons, Heine, p. 81.
} 
does not bode well. Modemity will arrive soon in Germany and those who are not prepared will suffer. The Prussian soldiers in Aachen, with their comical Pickelhaube (spiked helmets) will be among the first victims of the modernity that Heine preaches.

Ja, Ja, der Helm gefält mir, er zeugt Vom allerböchsten Witze!

Ein königlicher Einfall war's! Es fehlt nicht die Pointe, die Spitze!

Nur fürcht ich, wenn ein Genitter ensteht,

Zieht leicht so eine Spitze

Herab auf euer romantisches Haupt

Des Himmels modernste Blitze! $!^{174}$
It springs from the very highest wit;

Yes, yes, this belmet I like!

It was a notion befitting a king,

Not lacking a point, a spike!

But should a storm arise, I fear

The sky will be drawn by your spike And down upon your momantic bead Most modern lightning aill strike!

The spike, which Heine cannot resist from ridiculing, hearkens back to earlier times of ignorance and barbarism. Heine feels it necessary to point out the anachronism and explain his opinions. The Pickelhaube reminds him of the essence of the medieval past.

Das mabnt an Kreuzzug und Turnei, An Minne und frommes Dienen,

An die gedruckte Glaubenzeit, Wo noch keine Zeitung erschienen. ${ }^{175}$
It reminds me of toumeys and crusades,

When men were noble reared,

When faith was more than a printed word,

Before the first newspaper appeared.

The most regressive element in German culture and society, which Heine repeatedly attacks throughout the poem, is religion, the socially constrictive force that survived the experience of the French Revolution. In particular, Heine attacks the Catholic Church as one of the pillars of the Middle

\footnotetext{
174 "Deutschland," p. 100.

175 Ibid, p. 100.
} 
Ages, still working during the Vormärz to keep Germany repressed. ${ }^{176}$ In caput IV Heine comes upon the recently completed cathedral of Cologne, which lay unfinished since the time of Luther, only to be completed in 1842 by Friedrich Wilhelm IV--a Protestant king! The cathedral is, for Heine, a symbol of repression, which, begun by despots of the Middle Ages, was taken over by despots of his era.

Er sollte das Geistes Bastille sein,

Und die listigen Römlinge dacbten:

It was meant to be the mind's Bastille,

"In diesem Riesenkerker wird

Die deutsche Vernunft verschmachten!"177 And the Romish plan was clever.

"In this great prison the German mind Will pine away forever!"

Upon entering the cathedral in caput VII, Heine declares:

Es berrschte im ungeheuren Raum

Nur Tod und Nacht und Schweigen;

Es brannten Ampeln bie und da,

$U m$ die Dunkelbeit recht zu zeigen. ${ }^{178}$
Only silence and death and night

Ruled in that giant room;

Hanging-lamps burned bere and there

The better to show the gloom.

The cathedral, as a symbol for the Catholic Church, or even of religion for that matter, represents ignorance. ${ }^{179}$ In the realm of death and night the candles do not enlighten the darkness, they work to show it. Following his conception of religion as spiritual opium, Heine implies that religion serves not only to stifle efforts at self-emancipation, it also, as a consequence, supports

\footnotetext{
${ }^{176}$ Heine was a self-declared enemy of the Catholic tradition in Germany. However, he was also critical of Martin Luther and the Protestant tradition, in that they propped up Christianity at a time when it was ready to collapse on its own. Adrian del Caro, "Heine's Deutschland. Ein Wintermärchen Reflected in Nietzsche," Heine Jahrbuch, (1994), 194-201.

177 "Deutschland," p. 102.

178 Ibid., p. 111.

179 Grab, Heine als politischer Dichter, p. 100.
} 
the traditional forms of authority. ${ }^{180}$ The Three Kings of the East become animated as Heine approaches their chapel in the cathedral. They demand his respect as holy symbols of the past, but the modern poet Heine condemns them for being such creatures. He explains that although they still firmly grasp their scepters, their power is fading. ${ }^{181}$ With one fell swoop Heine equates the un-modern religious figures of the Three Kings with the three kings of the Holy Alliance: Prussia, Russia, and the Habsburgs--the chief conservative powers of post-Napoleonic continental Europe. Heine recognizes the alliance of throne and altar. He sees that the two are really one and the same. ${ }^{182}$

\section{Prussian Militarism}

In Deutschland Heine repeatedly digresses from his loftier philosophical criticisms in order to take jabs at contemporary people and institutions that he feels characterize Germany's backwardness. One such object of his ridicule is Prussia, his fiercest enemy. In caput III Heine visits Aachen, a western town which once enjoyed French rule, but after 1815 became part of larger Prussia. He notes that the people of Aachen are now oppressed and run about like dogs. He sees the over-powering presence of Prussia all around in the form of the hyper-obedient soldiers and he cannot restrain himself from ridiculing their character.

\footnotetext{
180 Ibid., p. 94.

181 Tbid., p. 112.

182 Ibid., p. 102.
} 
Sie stelzen noch immer so tief herum,

So kerzengerade geschniegelt, Als bätten sie verschluckt den Stock,

Womit man sie einst geprügelt. ${ }^{183}$
They stalk around so stiltedly, So sprucely bold upright, As though they've swallowed the whipping-rod That bloodied their backs last night.

In the Prussia of the Vormärz Heine saw a sinister mixture of

Romanticism and military tradition. ${ }^{184}$ This, he believed, was a possible danger for Germany--strict obedience with fantastical notions about national destiny. For Heine the danger is so pressing that he almost begins to falter when he retums to this theme in caput XVIII. In the garrison town of Minden the traveler spends a restless night in the fortress and he fears that he may never be set free. In his canopy bed he dreams that he, the harbinger of modernity, will become a Prometheus.

Ach die Gespenster schlepten mich fort, Und ich bab mich endich befunden An einer steilen Felsenwand;

Dort war ich festgebunden.

Der böse, schmutzige Betthimmelquast! Ich fand ibn gleichfalls wieder, Doch sah er jetzt wie ein Geier aus, Mit Krallen und schwarzen Gefieder.

Er glich dem preußischen Adler jetzt Und bielt meinen Leib umklammert; Er fraß mir die Leber aus der Brust, Ich habe gestöhnt und gejammert. ${ }^{185}$

\author{
Alas! The ghosts dragged me off. \\ I found myself at last \\ Upon a steep rocky wall; \\ There they bound me fast. \\ Thut exih filthy canopy fringe! \\ I found it here once more, \\ But it seemed to be a vulture now, \\ Of death-black feather and claw. \\ It looked like the Prussian eagle now, \\ And clutched me close, and ripped \\ The liver out of my gaping breast; \\ I groaned bitterly and wept.
}

Throughout the poem Heine continues with the theme of Prussia's oppressive nature. He recognizes Prussia's desire for hegemony and in caput

\footnotetext{
183 "Deutschland," p. 99.

${ }^{184}$ Grab, Heine als politischer Dicbter, p. 117.

185 "Deutschland" p. 138.
} 
XXI makes the off-handed joke that when all the countries of Europe offered to send relief for the rebuilding of Hamburg after its recent fire, the king of Prussia offered to send his troops. ${ }^{186}$ Heine recognizes Prussia as a threat to Germany's future as well as a personal threat to himself and he calls for action. His enemies are Germany's enemies. The fate of the poet is the fate of the nation. In caput III he sees the Prussian eagle on the post-sign of Aachen and calls for a savior.

Wer mir den Vogel herunterschießt, Mit Zepter und Krone belehn ich Den wackern Mann! Wir blasen Tusch Und rufen: "Es lebe der König!'"187

\author{
He who shoots the eagle down for me \\ Shall instantly be crowned \\ And we shall ory: "The king is alive!" \\ While guns and trumpets sound.
}

\section{The Philistine Nationalists}

The cultural philistines, who Heine believes make Germany intolerable due to their arrogance and ignorance, appear throughout Deutschland. They misinterpret the meaning of modernity and subvert progressive impulses for shallow aims. Heine finds their petty nationalism both repulsive and comical. In caput $\mathrm{V}$ Heine travels across the Rhine, which, speaking in the voice of an old man, recognizes the poet as his true son and tells to him of the mistreatment which he, as the symbol of Germany, has received from the philistine patriots, such as the poet Nicholas Becker (1809-1845). Father Rhine complains that the nationalists have condemned him to be a symbol of

\footnotetext{
186 Ibid., p. 144.

187 Ibid., p. 101.
} 
Germany's backwardness and chauvinism. Heine sees the Rhine as being the opposite. His comical exchange with Father Rhine give the river-god opportunity to lament the absence of the French, who understood him better than the Germans.

\author{
"Wenn ich es böre, das dumme Lied, \\ Dann möchte ich mir zerraufen \\ Den weißen Bart, ich möcbte fürwabr \\ Micb in mir selbst ersaufen! \\ Daß ich keine reine Jungfer bin, \\ Die Franzosen wissen es besser, \\ Sie baben mit meinem Wasser so oft \\ Vermischt ibr Siegergen'ässer. \\ Das dumme Lied und der dumme Kerl! \\ Er hat mich schmäblich blamieret, \\ Gewissermaßen hat er mich auch \\ Politisch kompromittieret. '188
}

\author{
"I feel like plucking out my beard \\ When bis stupid rbymes resound; \\ I could almost bid the world goodby \\ And in myself me drowned. \\ That I am not a stainless maid \\ The Frenchmen hove long known. \\ So often bas their victor's water \\ Been mingled with my own. \\ That stupid song, and that stupid man! \\ He slandered me with bis rot. \\ And, so to speak, politically, \\ Put me in a spot."
}

Heine believes that the true Germany has the potential for great feats in the cause of humanity, but those who wield power subvert its promise. He differentiates between love of the Fatherland and the crude patriotism of the philistines. ${ }^{189}$ Such men tum a blind eye to the cause of freedom in their search for national greatness and unity. Consequently, they become unknowing lackeys to the powers of the status quo. Heine meets one such philistine in caput II, who explains to the traveler how Germany will be united extemally and internally.

\footnotetext{
188 Ibid., p. 105.

${ }^{189}$ Grab, Heine als politischer Dichter, p. 116.
} 
"Der Zollverein" - bemerkte er -

"Wird unser Volkstum begründen,

Er wird das zersplitterte $V$ aterland

$Z u$ einem Ganzen verbinden.

Er gibt die äußere Einbeit uns,

Die sogenannt materielle;

Die geistige Einheit gibt uns die Zensur,

Die wabrhaft ideelle.

Sie gibt die innere Einbeit uns,

Die Einheit im Denken und Sinnen;

Ein einiges Deutschland tut uns not,

Einig nach außen und innen. "190
"The Zollverein" - the gentleman said,

"Will be our true foundation, And bind the dismembered Fatherland Into one great nation.

It will bring us material unity: An outwardly welded state;

While union of the soul, on the other hand,

Our censors will create.

They'll bring internal unity:

No rom for our minds that doubt.

We need a united Germany:

United within and without."

Heine feels that the blissfully ignorant nationalism of the era stems

from the same romantic notions that fueled Germany's romantic obscurantism.

The dreams of the patriotic Burschenschafter, with roots in the Wars of

Liberation, remain just that - dreams. The nationalists dream of Germany's

coming greatness, but Heine believes that such pretensions cannot be

actualized until Germany progresses and takes up arms for the cause of greater

humanity. Yet the Germans still dream.

Franzosen und Russen gebört das Land,

Das Meer gebört den Briten,

Wir aber besitzen im Luftreich des Traums

Die Herrschaft unbestritten.

Hier üben wir die Hegemonie,

Hie sind wir unzerstückelt:

Die andern Völker haben sich

Auf platter Erde entuickelt. ${ }^{191}$
The French and the Russians rule the land;

The British rule the sea;

But in the realms of dreams we own

Unchallenged mastery.

Here we become one mighty state,

Here, in dreams, we are crowned -

$W$ bile other peoples build their realms

Upon the level ground. -

Heine returns to this theme in caput XI. In the Teutoburg forest he thinks of Hermann, the German prince who defeated Varus and the Romans--

\footnotetext{
190 "Deutschlond" p. 98.

191 Ibid, p. 110.
} 
the hero who kept Germany for the Germans. Heine sees the mire and filth of that forest as the birthplace of German nationalism.

Das ist der Teutoburger Wald,

Den Tacitus beschrieben, Das ist der klassische Morast,

Wo V arus steckengeblieben.

Hier schlug ihn der Cheruskerfürst,

Der Hermann, der edle Recke;

Die deutsche Nationalität,

Die siegte in diesem Drecke. ${ }^{192}$
This is the forest of Teutoburg

Of Tacitus' report.

This is the classical morass

Where Varus was stopped short.

Here be was faced by the Cheruscan chief,

Hermann, of noble blood;

And bere the German nation rose

Victorious from the mud.

\section{The Radicals and Party Politics}

Heine devotes a good portion of Deutscbland to addressing his particular position among the opposition in Germany. He knows that he has many critics who chide him for his ambiguous political stance, for never creating or adhering to a political manifesto. Yet Heine, especially in the early 1840 s, sees that he has moved towards the radicals. In caput XII he hears the howl of the radical wolves in the forest. They know of his arrival in Germany and he takes the opportunity to address them.

Der Schafpelz, den ich umgehängt Zuweilen, um mich zu wärmen, Glaubt mir's, er bracbte mich nie dabin, Für das Glück der Schafe zu scbwärmen.

Ich bin kein Schaf, ich bin kein Hund, Kein Hofrat und kein Schellfisch Ich bin ein Wolf geblieben, mein Herz Und meine Zäbne sind wölfisch. ${ }^{193}$
Believe me, though I sometimes wore $A$ coat of wool to keep The cold away, I was never convinced To fight in the cause of the sheep.

I am no sheep, no shell-fish, no dog; I play no councilor's part; I've stayed a wolf through all the years, With wolfish teeth and beart.

192 Ibid., p. 118.

193 Ibid., p. 122. 
As noted, the 1840 s were for Germany a time of increasing politicization. The newly developing political parties of the Vormärzwere a matter of much excitement and wonder for many middle-class Germans. Heine saw and understood this development. In Deutschland he chooses to acknowledge his tendencies towards political aloofness. He does not share the en thusiasms of his fellow countrymen. For Heine, the political parties, the Liberals, Democrats, etc., are ineffectual and ridiculous. In caput XX he slyly explains his position to his mother, who has prepared him a meal.

"Mein liebes Kind! Wre denkst du jetzt? Treibst du noch immer aus Neigung Die Politik? Zu welcher Partei Gehörst du mit Überzeugung?”

Die Apfelsinen, lieb Mütterlein, Sind gut, und mit wahrem Vergnügen Verschlucke ich den süßen Saft Und ich lasse die Schalen liegen. ${ }^{194}$
"My darling child! What are your views? Do you still take note of the trends? What party do you belong to now? What sort of folks are your friends?"

The oranges, dear mother, Are good - and with genuine zeal I swallow down the last sweet drop, And lay aside the peel.

The harbinger of modemity does not concern himself with party politics. Heine is concerned with sensuality, with hedonism. Heine can not join one of the Vormärz parties because his opposition is more than political; it centers around a societal and aesthetic ideal. ${ }^{195}$ To belong to a party would limit his vision as well as stifle his voice.

\footnotetext{
194 Ibid., p. 142.

195 Grab, Heine als politischer Dichter, p. 95.
} 


\section{The French Revolution and Modernity}

Heine's belief that the French Revolution was the primary event that ushered in the modern world can be found in a number of places in Deutschland. He presents the Revolution as a progressive step in the history of mankind, not as a period of turmoil and disruption, as the conservative powers of Germany would have it remembered. In caput XVI Heine dreams that he has an audience with one of the greatest figures of Germany's medieval past-the fabled savior, Barbarossa, who lies waiting in the Kyffhäuser mountain for his time to return and lift the German nation to greatness. Barbarossa was a popular romantic character during the Vormär, and Heine knew that by satirizing the legend he would be attacking one of the most beloved national legends and heroes. But for Heine, the figure of the sleeping savior-king is the epitome of Germany's backwardness. The legend of Barbarossa symbolizes Germany's problems. In the dream the poet comes to the vast cave of the fable-king. There is a sleeping army, a stocked armory, and stables. Yet the king laments that he is still not ready. He asks Heine to give him news of the outside, as he has heard nothing since the time of Frederick the Great. It is no coincidence that Heine uses this opportunity to tell the medieval king about the tragic fate of Louis XVI and Marie Antoinette. He endeavors to explain how nobility have been treated since 1789 . 
Der König Ludwig der Fünfzehnte starb Ganz rubig in seinem Bette,

Der Sechzehnte aber ward guillotinient

Mit der Königin Antoinette.

Die Königin zeigte großen Mut,

Ganz wie es sich gebübrte,

Die Dubarry aber weinte und schrie,

Als man sie guillotinierte. -

Der Kaiser blieb plötzlich stillestebn, Und sab mich an mit den stieren Augen und sprach: "Um Gottes willn, Was ist das, guillotinieren?"'16
King Louis the Fifteenth died in bed,

His passing was serene;

The Sixteenth, though was guillotined

With Antoinette, bis queen.

The queen, as befits a royal nife,

Went with brave demeanor,

Dubarry, though, shed tears and shrieked,

When they came to guillotine ber. ---

The emperor suddenly stood still.

"By God, what does it mean?"

He looked at me with staring eyes,

"What is this guillotine?"

Heine explains the history of the new machine and goes on to tell to

Barbarossa how it functions, for killing nobility as well as commoners.

Du wirst bier an ein Brett geschnallt; -

Das senkt sich; - du wirst geschoben

Geschuinde zuischen zwei Pfosten; -es hängt

Ein dreieckiges Beil ganz oben; -

Man zieht eine Schnur, dann schießt herab

Das Beih ganz lustig und munter; -

Bei dieser Gelegenheit fällt dein Kopf

In einem Sack binunter.

Der Kaiser fiel mir in die Red.

"Schweig still, von deiner Maschine

Will ich nichts wissen, Gott bewahr,

Daß ich mich ibrer bediene!

Der König und die Königin!

Geschnallt an einem Brette!

Das ist ja gegen allen Respekt

Und alle Etikette!

Und du, wer bist $d u$, daß du es wagst,

Mich so vertraulich zu duzen?

Warte, du Bürschchen, ich werde dir schon

Die kecken Flügel stutzen!

Es regt mir die innerste Galle auf,

Wenn ich dich böre sprechen,
First they strap you to a board.

It drops - they quickly shove you

Between two posts - a three cornered ax

Hangs directly above you; -

They pull a cord, then downward shoots

The spritely blade, - and crack

Your head immediately drops

Into a waiting sack.

The emperor broke in on my words: "Shut up!

Enough of your machine!

God forbid that I should come

To use a guillotine!

Strapped! The king and the queen!

Strapped onto a plank!

That goes agcinst all etiquette

And all respect of rank!

And who are you, that you dare to be So intimate with me?

I'll clip your impertinent wings, young scamp!

Just wait, just wait and see.

When I listen to the things you say

My very innards are stirred.

196 "Deutschland" p. 132. 
Dein Odem schon ist Hochverrat

Und Majestätsverbrechen. '197
Your breath is itself a crown-offense;

High treason's in every word!"

Heine, both in his tale and in his manner of speech, shows the medieval king that in the modem world the traditional nobility no longer command the respect and privilege they once enjoyed. With the death of Louis XVI came the complete end of the ancien regime. Kings and queens are not needed in the modern world. They belong in the past. For Heine, Barbarossa is a relic and he tells him so.

"Herr Rotbart - rief ich laut -, du bist Ein altes Fabelwesen, Geh, leg dich schlaffen, wir werden uns Auch obne dich erlösen.

Die Republikaner lacben uns aus, Sehn sie an unserer Spitze So ein Gespenst mit Zepter und Kron; Sie rissen schlechte Witze.

Auch diene Fabne gefallt mir nicht mebr, Die altdeutschen Narren verdarben Mir schon in der Burschenschaft die Lust $A n$ den schwarz-rot-goldnen Farben.

Das beste wär, du bleibest zu Haus, Hier in dem alten Kyffhäuser Bedenk ich die Sache ganz genau, So brauchen wir gar keinen Kaiser. "198
"Sir Redbeard! - I cried out loud. You're a mythical creation. Go, off to sleep! Without your belp We'll work out our salvation.

The Republicans would laugh at us If a ghost with scepter and crown Came marching as the bead of our ranks They'd laugh us out of town.

And I care not for your flag these days;

No Longer am I thrilled

By your black-red-gold - I got sick of it In the days of the student guild.

It would be best if you stayed at bome Here in the old Kyffhäuser When I consider the matter carefully It's clear we don't need an emperor."

There is an equation of Barbarossa with German nationalism. ${ }^{199}$ Heine believes that romanticism and nationalism share the same roots, and although

\footnotetext{
${ }^{197}$ Tbid, p. 133.

198 Ibid., p. 134.

199 Grab, Heine als politischer Dichter, p. 109.
} 
nationalism is a new phenomenon, it is also backward looking-- it cannot aid in creating a better future.

Earlier in the poem Heine invokes the image of another emperor, one who is not a dreamy symbol of the past-Napoleon, the antithesis of Barbarossa. He devotes all of caput VIII to the memory of this hero and to a comparison of the hope that existed in Germany during the brief revolutionary period of 1830 , as opposed to the dreary situation which exits during the 1840 s. The events of that year rekindled the ideas of the French Revolution, and Heine sees how things have changed since he left.

Wir fubren durch Mülbeim. Die Stadt ist nett. Die Menschen still und fleißig.

$W$ ar dont zuletzt im Monat Mai

Des Jahres einunddreißig.

Damals stand alles im Blütensibmuck

Und die Sonnenlichter lachten,

Die Vögel sangen sebnsuchtvolh.

Und die Menschen bofften und dachten -

Sie dachten: "Die magere Ritterschaft

Wird bald von hinnen reisen,

Und der Abschiedstrunk wird ibnen kredenzt

Aus Langen Flaschen von Eisen!

Und die Freibeit kommt mit Spiel und Tanz Mit der Fahne, der weiß-blau-rotten;

Vielleicht holt sie sogar aus dem Grab

Den Bonaparte, den Toten!"

Ach Gott! Die Ritter sind immer noch bier,

Und manche dieser Gäuche,

Die spindeldürre gekommen ins Land

Die haben jetzt dicke Bäuche.200
We drove through Müllheim: a pretty town;

Its people get things done.

I saw them last in the month of May,

In Eighteen Thirty-one.

Everything then was blossom-crowned;

Sunbeams were laughing then;

Full of longing sang the birds;

And there were hopeful men.

"Soon the lean barons will ride away,"

The people used to think,

"And irn bottles will be drained

For a good-bye drink.

And freedom will come with song and dance,

With ber flag, the white-blue-red;

Perhaps she'll even be able to fetch

Napoleon from the dead!"

My God! The barons still are bere! And many who come this way -

Gawky fellows, dry as bone -

Canry big bellies today.

200 "Deutschland," p. 115. 
Again Heine equates freedom with sensuality and emancipation with the French Revolution and Napoleon. Yet he sees that the springtime of hope did not last once the remaining feudal powers returned. Napoleon, not Barbarossa, is the mythic figure Heine believes can save Germany. The people of Mülheim once enjoyed French rule, and now they suffer under oppression, waiting for freedom to return. Heine makes his Bonapartism quite clear when he describes the scene he witnessed when Napoleon's body was brought back from St. Helena to Paris.

Ich weinte an jenem Tag. Mir sind Die Tränen ins Auge gekommen, Als ich den verschollenen Liebesruf, Das Vive l'Empereur! vernommen. ${ }^{201}$
I couldn't help but weep that day:

My eyes grew dim with tears When that old cry, "Tive l'Empereur!" Resounded in my ears.

\section{Germany's Hidden Revolution and the Poet's Death}

Heine's perception of himself as the enemy of the Middle Ages comes up numerous times throughout the poem, and he is quick to show that it is his ideas that make up his arsenal of weapons. However, he presents an interesting dilemma. His weapons will not only destroy the medieval remnants in Germany, they will also destroy him because he knows that he too, as a poet--the nobility of talent--cannot exist in the modern world. In caput VI Heine describes the power of his ideas. Returning to his formulation about the hidden force of ideas throughout history, he creates one of the darkest and most fascinating figures in Deutschland-a demon-like figure whom the poet 
claims to see while he writes at his desk. This figure comes to Heine, yet stays in the background, silently holding an ax. It does not disturb him; it remains at a distance. The shadowy figure reappears to Heine in a dream in which he wanders about the streets of Cologne at night. It follows him step for step. The poet confronts his companion and demands to know his identity and intentions. The figure answers:

"Tch bin kein Gespenst der V ergangenheit, Kein grabenstiegener Strobuisch, Und von Rhetorik bin ich kein Freund, Bin ach nicht sebr philosophisch.

Ich bin von praktischer Natur, Und immer schweigsam und rubig, Doch wisse: was du ersonnen im Geist, Das fübr ich aus, das tu ich.

Und gebn auch Jabre drüber bin, Ich raste nicht, bis ich verwandle In Wirklichkeit, was du gedacht; Du denkst, und ich, ich handle.

Du bist der Richter, der Büttel bin ich, Und mit dem Gehorsam des Knechtes $\checkmark$ ollstreck ich das Urteih das du gefällt, Und sei es ein ungerechtes.

Dem Konsul trug man ein Beil voran, $Z u$ Rom, in alten Tagen. Auch du bast deinen Liktor, doch wird $D$ as Beil dir nachgetragen.

Ich bin dein Liktor, und ich geb Beständig mit dem blanken Rechtbeile hinter dir - ich bin Die Tat von deinem Gedanken. '202
"I am no scarecrow, no ghost of the past

Out of the grave arising;

And I am no friend of rhetoric,

Do little philosophizing.

I'm of a practical character.

The calm and silent kind.

But know: I carry out, I do

All that you've had in mind.

And even though the years go by,

I find no satisfaction

Till thought becomes reality;

You think, and I take action.

You are the judge; the beadsman am I, Who stands and awaits your nill; $B e$ your judgment right or wrong, Obediently I kill.

The ax of the consul in ancient Rome Went first, may I remind you. You've got your lictor, too; but now The ax is carried behind you.

I am your lictor; with shiny ax I follow close behind

On all your travels - I am the deed, The offspring of your mind."

The figure is the hidden violence of Heine's thoughts about modemity.

He is the Hegelian spirit taking material form. Heine sees his ideas as 
inherently violent. The lictor follows him into the Cologne Cathedral. When the Three Kings of the East become animated and Heine denounces them as spirits of the past, the lictor smashes the chapel and destroys the kings. The dream ends with Heine's chest spouting blood while the lictor performs his violence. The poet realizes that he too belongs to the past, and he remains at heart a Romantic, despite his revolutionary ideas. ${ }^{203}$ The irony is that he will be one of the first victims of the revolution that he preaches. ${ }^{204}$

\section{The Future of Germany and the Faltering of Heine's Idealism}

In caput XXVI Heine introduces one of the most curious paradoxes of the entire poem. His progressive idealism crashes in upon itself when confronted with the social and political reality of his era. Despite his initial optimism, at the climax of the poem (caputs XXII-XXVI) Heine becomes decidedly pessimistic when he considers the future of Germany. On the streets of Hamburg, one of the primary cities of his youth, he meets an irresistible harlot-Hammonia, the patron goddess of the town and the daughter of the Shellfish Queen and Charlemagne. Hammonia tries to coax Heine into retuming to Germany, where she says, all things are not so bad.

" $J a$, daß es uns früher so schrecklich ging, In Deutscbland, ist Übertreibung:

\footnotetext{
202 Ibid., p. 109.

203 Grab, Heine als politischer Dichter, p. 104.

204 Robertson, Heine, p. 70.

205 "Deutschland" p. 156.
}

"To say that things were hopeless here

Is a gross exaggeration; 
Man konnte entrinnen der Knechtschaft wie einst Im Rom, durch Selbstentleibung.

Gedankenfreibeit genoß das Volk, Sie war für die großen Massen, Beschrönkung traf nur die g'ringe Zabl Derjen'gen, die drucken lassen.

Gesetzlose Willkür herrschte nie, Dem schlimmsten Demagogen Ward niemals obne Urteilspruch Die Stattskokarde entzogen.

So übel war es in Deutschland nie, Trotz aller Zeitbedrängnis Glaub mir, verbungert ist nie ein Mensch In einem deutschen Gefängnis. ${ }^{1205}$
You could break your chains, as in Rome, By self-extermination.

The populace had freedom of thought, -

The greatest number possessed it;

Only the few who published books

Were ever really molested.

Lawless tyranny never ruled;

Demagogues - even the worst -

Never lost their citizenship,

Without being sentenced first.

And even in the hardest times

Euil did not prevail -

Believe me, no one ever starved

In any German jail."

Hammonia pleads with Heine, her favorite poet, and even offers to

show him a great secret--the future of Germany! She has him swear never to

tell, but he cannot pass up the opportunity. It is here that Heine's vision falters

but his satire soars. Hammonia has him look into a pot under Charlemagne's

throne, which she keeps in the comer of her room. It is not the throne which

the emperor sat on during the day, but the pot lies under the throne he sat on

at night!

Was ich gesehn, verrate ich nicht,

Ich habe zu schweigen versprochen,

Erlaubt ist mir zu sagen kaum,

Gott! Was babe ich gerochen! --

The things I saw, I won't betray -

I promised not to tell

I'm barely permitted to report:

God! What a smell!

Ich denke mit Widenwillen noch

Against my will those cursed, vile An jene schnöden, verfluchten Aromas come to mind:

Vompielgerüche, das schien ein Gernisch

The starting stink, that seemed to be

Von altem Kobl und Juchten.

Old cabbage and leather combined.

Entsetzlich waren die Düfte, o Gott!

Die sich nacher erbuben;

And after this -o God! - there rose

Such monstrous, loathsome stenches;

200 Ibid., p. 160. 
Es war, als fegte man den Mist

Aus sechsunddreißig Gruben. -

Ich weiß wobh was Saint-Just gesagt

Weiland im Woblfabrtsausschuß:

$M a n$ beile die große Krankbeit nicht

Mit Rosenöl und Moschus -

Doch dieser deutsche Zukunftsduft

Mocht alles überragen,

$W$ as meine Nase je geahnt -

Ich konnt es nicht länger ertragen _-206
It was as though the dung were swept

From six and thirty trenches -

I know very well what Saint-Just scid

Of late to the Welfare Board -

Neither with altar of roses nor musk

Can the great disease be cured.

But all the other smells were put to shame

By this prophetic scent -

No longer could my nostrils bear

That vile presentiment.

The thirty-six trenches (or alleys) which Heine speaks of are the thirtysix states of Germany which existed in 1843 . He proclaims that the future of Germany will be shaped by the needs of the masses--there will be proletarian revolution, not for the sake of beauty or freedom, but for bread. The logic is powerfully simple. He will not topple the princes and clerics of Germany; men such as Marx will. Heine's progressive idealism, with its emphasis on freedom and aesthetics, will not be the driving force behind any changes. Socialism will win the future, and Heine believes that it will not be beautiful. By the end of Deutschland: Ein Wintermärchen his optimism is gone. The future stinks of rotten feudalism and the rough skin of the worker. ${ }^{207}$

\section{Heine's Warning}

Deutschland ends with a waming. Heine leaves behind his ideas about modernity and the possible future to address a personal enemy. He issues an indirect threat to King Friedrich Wilhelm IV of Prussia. ${ }^{208}$ Heine says that he

\footnotetext{
207 Grab, Heine als politischer Dicbter, p. 116.

208 Ibid, p. 118.
} 
possesses, like his model Aristophanes, true insight as well as satirical talent and that these two elements combine to make a powerful weapon that can hurt those who would work to mistreat the poet. He can damn their memory, which is more than they can do to him. Heine feels it necessary to explain to the king that he should be more careful in his treatment of Germany's most powerful voice.

Doch gibt es Höllen, aus deren Haft Unmöglich jede Befreiung; Hier bilf kein Beten, obnmächtig ist hier Des Welterlösers V erzeibung.

But there are bells from whose confines No amnesty avails No proyers will belp, and even the word Of our Redeemer foils.

Kennst du nicht die Hölle des Dante nicht,

Hove you not beard of Dante's belh, Die schrecklichen Terzetten? Wen da der Dichter hineingesperrt, Den kann kein Gott mebr retten The tercets that flamed from his pen? He whom the poet imprisons there Can never go free again -

Kein Gott, kein Heiland erlöst ibn je Aus diesen singenden Flammen! Nimm dich acht! Daß wir dich nicht $\mathrm{Zu}$ solcher Hölle verdammen. ${ }^{209}$

No God, no savior can free bim from The conflagration of rbyme!

Beware, lest we bold you in such a Hell Until the end of time.

By the time Heine wrote Deutschland: Ein Wintermärchen, he knew that he was an outlaw in the eyes of Prussia and that if he were caught he would suffer. Heine sums up his conception of himself in caput XVIII when a Prussian corporal of Minden asks him his name. Unable to tell him the truth he answers:

Ich beiße Niemand, bin Augenarzt Und steche den Star den Riesen. ${ }^{210}$
My name is No-one, I am an oculist I open the eyes of giants. 211

\footnotetext{
209 "Dextschland" p. 165.

210 Tbid., p. 136.

211 In this context the German verb stechen translates as to open. However, the literal translation is to pierre. Heine's statement can probably be taken both ways.
} 
There are many motivations to be found in Deutschland. Heine does not limit himself to just one critique or enemy. Yet the core of the poem is directed towards the peculiarity of Germany during the Vormärz-its inability to understand the true meaning of its own history and to accept modemity. Yet Heine's insight, his acurate perception of the change from the old to the new, cannot protect him from falling victim to the violence that he himself welcomes. Deutschland: Ein Wintermärchen is a poem about the Vormär and simultaneously a poem about the poet. Heine saw himself as the true man of his era. Perhaps it could be said that he was the spirit of his age in material form; and if that is true, those contradictions and paradoxes within his character mirror those of his time. 


\section{CONCLUSION}

In 1847 a series of seizures had caused Heine to withdraw from public life, and as a consequence, he did not feel the tremblings that preceded the outbreak of revolt. In May of 1848 he suffered a final physical breakdown that resulted in permanent paralysis. When revolution came to France in February 1848, Heine played no part. His chronic illness caused him to remain indoors and because of the turbulence outside his windows he moved to the suburbs of Paris. He was to spend the remaining eight years of his life on a stack of mattresses, which he called his "mattress-grave." He was paralyzed and relied heavily on opium to relieve his unrelenting pain. This tragedy did not end his productivity, but it can be seen as a tuming point in his career. As Heine's body deteriorated he began to question the entire basis of his intellectual essence - his sensualism, worldliness, advocacy of erotic and physical freedom. ${ }^{212}$ In his collection of poems entitled Romanzero (1851), Heine relates how, when tragedy struck, his previous love of beauty could no longer help him. He fictitiously tells of the moment in which he collapsed in the Louvre in front of that great symbol of beauty, the Venus de Milo:

212 Sammons, Heine, p. 119. 
I lay at her feet for a long time, and I wept so hard that I must have moved the stone to pity. The goddess also gazed down on me with compassion, but at the same time so disconsolately as if to say: "Don't you see that I have no arms and so cannot help."213

Heine did manage to write some reports to Germany about the February Revolution in Paris. At one point he was caught between two barricades, as the livery which was being used to transport him was requisitioned to become one of those defensive structures. ${ }^{214}$ In another dispatch he tells of how the people of Paris were arming themselves and plundering the sweet jams of the Palais-Royal while Louis Phillipe was forced to eat the bitter jams of exile in England. ${ }^{215}$ Yet due to the limitations of his illness, Heine could not venture out into the action and fully grasp the situation. The majority of his reports are secondhand and rather vague. Enthusiasm towards the Revolutions of 1848, both in France and in Germany, is lacking. In April 1848 he wrote a letter to his friend, Alfred Meißner, in which he distanced himself from the men of the Revolution. "You know that I was never a republican and I am not astounded that I never became one. What the world now undertakes and hopes for is totally foreign to my heart." 216

\footnotetext{
213 "Romanzero," The Complete Poems of Heinrich Heine, ed. Hal Draper, (Shurkamp,Insel, 1982), p. 696. 214 “Die Februarrevolution," Heines Werke, vol. 5. p. 305. 
As the forces of reaction began their assault in the summer of 1848 , Heine reasserted his distance from the events in a letter to his publisher, Julius Campe.

I have nothing to say about the events of our times. It is universal anarchy, world wide muddle, God has become insane! The old man should be locked up because of all that is going on. It's the fault of the atheists who angered him. ${ }^{217}$

The revolution which Heine predicts in Deutschland: Ein Wintermärchen arrived, but he wanted no part in it! Even his initial enthusiasm for Louis Napoleon quickly disappeared after he came to see, as did Marx, that the nephew was not the uncle--he was a farce. Heine came to believe that the ideas of freedom, honor, and equality, which were the beautiful dreams of the eighteenth century, not to mention the foundation for his previous conception of modernity, had been trampled underfoot and crushed by the ineptitude of the revolutionaries and the violence of the counter-revolutionaries. ${ }^{218}$

Heine's opinions on the situation in Germany during 1848/49 were equally as bleak. He saw the entire uprising as a failure due to a misunderstanding on the part of the revolutionaries as to what they really should be fighting for. The revolts in Berlin and Vienna, the Frankfurt Parliament, and the resistance of the radicals were all for naught. National chauvinism had replaced freedom as the revolutionary rally and the backward

217 Ibid., p. 121. 
Germans still slept in their in winter hibernation. In 1850, in a poem entitled

"Michel nach dem März" Heine reiterates the ineptitude of the Germans.

Solang ich den deutschen Michel gekannt,

War er ein Bärenbäuter;

Ich dachte im März, er hat sich ermannt

Und handelt fürder gescheuter.

Wie stolz erhob er das blonde Haupt

Vor seinen Landesvätern!

Wie sprach er - was doch unerlaubt -

Von bohen Landesverrätern.

Das klung so süß zu meinem Obr

Wie märchenhafte Sagen,

Ich füblte, wie ein junger Tor,

Das Herz mir wieder schlagen.

Doch als die schwarz-rot-goldne Fahn,

Der altgermanische Plunder,

Aufs neu erschien, da schwand mein Wabn

Und die süßen Märchenwunder.

Ich kannte die Farben in diesem Panier

Und ibre Vorbedeutung:

$V$ on deutscher Freibeit brachten sie mir

Die schlimmste Hiobszeitung.

Schon sab ich den Arndt, den Vater Jahn -

Die Helden aus andern Zeiten

Aus ibren Gräbern wieder nahm

Und für den Kaiser streiten.

Die Burschenschaftler allesamt

Aus meinen Jünglingsjabren,

Die für den Kaiser sich entflammt,

Wenn sie betrunken waren.

Ich sah das sündenergraute Geschlecht

Der Diplomaten und Pfaffen,

Die alten Knoppen vom römischen Recht,

Am Einbeitstempel schaffen -

Derweil der Michel geduldig und gut

Begann zu schlaffen und schnorchen.
The Germon Michaeh I knew from the stort,

Was a sluggish lavy poke;

I thought in March be had plucked up beart, Wiser since be awoke.

How proudly be raised his fair-haired bead Before his rulers' faces,

And spoke - although probibited -

Of traitors in bigh places.

Upon my ear it rang so sweet

Like an old beroic story,

And I, young fool, felt my heart beat

With a wild new' glimpse of glory.

But then the black-red-golden flag,

The old German trash, unfurled;

Illusions faded before this rag,

Illusions of a new world.

I knew this flag, I knew those bues,

I knew it was portending

For Greman freedom the worst of new's,

$A$ sorry Job-like ending.

I saw bow Arndt and Father Jahn -

The champions of yesterday -

Were rising from graves and marching on

To fight for the Kaiser's sway;

And all the lads of the Burschenschuft

Back in my youthful years

Who, drunks as lords, beld cups aloft

To toast the Kaiser with cheers;

And diplomats and priests I saw,

The whole tribe of sinful swine,

Old myrmidons of Roman law,

Busy at Unity's shrine -

While patient Michael good old fool

Slept on through all these things,

${ }^{218}$ Ibid., p. 121.

219 "Michel nach dem Märr," Heines Werke, vol. 1. p. 196. 
Und nieder ervachte unter der Hut

Von vierunddreißig Monarchen. ${ }^{219}$
And woke to find himself under the rule

Of four-and-thinty kings.220

The failure of Germany to progress in 1848 was, for Heine, an affirmation of his fears, but by this stage in his life fatalism had become a recurrent theme. Indeed in this poem he speaks of Job, a figure whom he came to resemble on his mattress grave. The radical first poet of the modern, the advocate of beautiful yet committed art, chose to simply withdraw from his own time. The irony of Heine's change is astounding.

As he had once shifted from Romantic to radical, Heine after 1848 shifted once again. The new character he assumed was pessimistic and dark. ${ }^{221}$ Much has been made of his return to religion. It was one of the primary reasons for his estrangement from men such as Marx, who had once believed Heine to stand firmly on their side. ${ }^{222}$ With the end of the Vormär, the exiled German writer, the self-proclaimed true voice of the opposition, pursued an independent path.

The radiant lyricism of his early poetry, the venomous sarcasm of his prose, and the obdurate skepticism of his politics conspired to obscure an aspect of Heine's character which, though it found its overt expression in the work of his final years, was a dark presence from the very beginning--a basically tragic sense of life. ${ }^{223}$

\footnotetext{
220 Translation - The Complete Poems of Heinrich Heine, p. 741.

221 Reeves, Poetry and Politics, p. 179.

222 Peter Demetz, Marx, Engels, and the Poets: Origins of Marxist Literary Criticism, trans. J.Sammons. Heine. (Chicago and London: University of Chicago Press, 1967), p.75.

223 Pawel, The Poet Dying, p. 14.
} 
Heine had spumed religion for most of his life, but the tragedy of his situation forced him to reflect upon the greater questions of existence. The poems of his last years represent an unsatisfied longing for life and a return to melancholy which was characteristic of Heine's early verses. In "Zum Lazarus" the ironies of life are put into the form of questions.

Laß die heil'gen Parabolen,

Laß die frommen Hypothesen -

suche die verdammten Fragen

Obne Umschweif uns zu lösen.

Warum schleppt sich blutend, elend,

Unter Kreuzlast der Gerecbte,

Wäbrend glücklich als ein Sieger

Trabt auf hobem Roß der Schlechte?

Woran liegt die Schuld? Ist etwa

Unser Herr nicht ganz allmächtig?

Oder treibt er selbst den Unfug?

Ach, das wäre niederträchtig.

Also fragen wir beständig,

Bis man uns mit einer Handvoll

Erde endich stopft die Mäuler -

Aber ist das eine Antwort?
Drop those holy parables and

Pietist hypotheses:

Answer us these damning questions -

No evasions, if you please.

Why do men stagger, bleeding,

Crushed beneath their cross's weight,

While the aicked ride the high horse,

Happy victors blest by fate?

Who's to blame? Is God not mighty,

Not with power panoplied?

Or is evil His oun doing?

$A h$, that would be vile indeed.

Thus we ask and keep on asking,

Till a bandful of cold clay

Stops our mouths as last securely.

But pray tell, is that ten an answer?

\section{Heine in the Vormärz}

As a general definition, the Vormärz is a era of transition in German history. Many of the themes that would later shape the nineteenth century took shape from 1815-1848: the growth of a market economy, the rise of the bourgeoisie, nationalism, and Gallophobia, among others. As well as being a watershed for future events, the Vormärz was also a period where themes from Germany's past were still extant: the rule of the aristocracy, the inequality of

224 "Zum Laqarus,"The Poet Dying, p. 234. (German and English). 
the classes, the command of the prince over the daily life of the individual. The Vormärz was the era in which the old clashed with the new. The French Revolution had come, but after its departure only its idealism remained--and only a select few chose to recognize this. ${ }^{225}$

Where does Heinrich Heine's significance lie in the Vormär? That question can be answered in a variety of ways. First, although he was not a philosopher, he was steeped in the philosophy of his day. Heine can be seen as a link, a juncture--much like the Vormärz itself--between different trains of thought: between Hegel and Marx; between Romanticism and political poetry; between the pure art of Goethe and the engaged art of the nineteenth century. Second, many figures of the Vormär, such as Mettemich, recognized that life was changing, Heine was able to give voice to this recognition, although he, himself, was not always sure of what to make of it. He did come to eventually formulate a concept as to the meaning of modemity, but it was an individual understanding which his contemporaries either did not, or could not, understand. A third reason for evaluating Heine's importance in the Vormär is the oppositional stance he took up in the 1840 s--during the creation of Deutschland. Some have come to see that poem as the zenith of Vormärz

225 Vierhaus, "Vormärz," p. 367. 
political literature. ${ }^{226}$ In its paradoxes it captures the essence of the era, much like Heine himself.

226 Sammons, Heine, p. 108. 


\section{Bibliography}

Arendt, Dieter, "Parabolische Dichtung und politsche Tendenz: Eine Episode aus den Bädern von Lucca." Heine Jabrbuch (1970), 41-57.

Amold, Matthew, Essays in Criticism. First Series. (London: MacMillan and Co., 1865).

Becker, Eva D., "Klassiker in der deutschen Literaturgeschichtsschreibung zwischen 1780 und 1860." Zur Literatur der Restorationsepoche, 1815-18+8. Ed. Jost Hermand and Manfred Windfuhr. (Stuttgart: J. B. Metzlersche Verlagsbuchhandlung, 1970). p.349-370.

Beutin, Wolfgang et al., Deutsche Literaturgeschichte: Von den Anfängen bis zur Gegenwart. (Stuttgart: J. B. Metzlersche Verlagsbuchhandlung, 1989), p.208-258.

Craig, Gordon, "Heinrich Heine and the Germans." The Politics of the Unpolitical: German Writers and the Problem of Power. (New York and Oxford: Oxford University Press, 1995). p.125-142.

Del Caro, Adrian, "Heine's Deutschland: Ein Wintermärchen Reflected in Nietzsche." Heine Jabrbuch (1994), 194-201.

Demetz, Peter, Marx, Engels and the Poets: Origins of Marxist Literary Criticism. Trans. J. Sammons. (Chicago and London: University of Chicago Press, 1967).

Fuller, Steven Nyole, The Nazi's Literary Grandfather: Adolf Bartels and Cultural Extremism, 1871-1945. (New York: Peter Lang, 1996).

Gilman, Sander and Peter Hohendahl, "Introduction."_Heinrich Heine and the Occident: Multiple Identities, Multiple Receptions. Ed. S. Gilman and P. Hohendahl. (Lincoln and London: University of Nebraska Press, 1991), p.1-18.

Grab, Walter, Heinrich Heine als politischer Dichter. (Frankfurt: Büchergilde Gutenberg, 1982).

Hamerow, Theodore, Restoration, Revolution, Reaction: Economics and Politics in Germany, 1815-1871. (Princeton: Princeton University Press, 1958). 
Heine, Heinrich, "Atta Troll." Heines Werke. vol. 2. (Berlin and Weimar: Aufbau-Verlag, 1964), p.7-88.

"Deutschland: Ein Wintermärchen." Heines Werke. vol. 2. p.91-165.

"Die Bäder von Lucca." Heines Werke. vol. 3. p.227-307.

"Die Februarrevolution." Heines Werke. vol. 5. p.303-313.

"Die romantische Schule." Heines Werke. vol. 4. p.185-326.

"Die schlesischen Weber." Heines Werke. vol. 1. p.174.

"Die Tendenz." Heines Werke. vol.1. p.153.

"Enfant Perdu." Heines Werke. vol. 1. p.290.

"Für die Mouche." Heines Werke. vol. 1. p.440-445.

"Ich lieb eine Blume." Heines Werke. Band 1. p.120.

"Lobgesänge auf König Ludwig." Heines Werke. Band 1. p.16t.

"Ludwig Böme: Eine Denkschrift." Heines Werke. Band 5. p.165-302.

"Michel nach dem Mär. Heines Werke." Band 1. p.196-197.

"Romanzero." The Complete Poems of Heinrich Heine. Ed. Hal Draper. (Suhrkamp/Insel, 1982.)

"Warnung." Heines Werke. vol. 1. p.123.

"Zum Lazarus." The Poet Dying: Heinrich Heine's Last Years in Paris. Emst Pawel. (New York: Farrar, Straus, and Giroux, 1995). p.234.

"Zur Geschichte der Religion und Philosopbie in Deutschland." Heines Werke. vol. 5. p.7-142. 
Heine, Heinrich, Translations:

The Complete Poems of Heinrich Heine. Ed. Hal Draper. (Suhrkamp/Insel, 1982).

The Poetry of Heinnich Heine. Ed. Frederic Ewen. (Secaucus: Citadel Press, 1969).

Hermand, Jost, “Allgemeine Epochenprobleme." Zur Literatur der Restorationsepoche, 1815-1848. Ed. J. Hermand and M. Windfuhr. (Stuttgart: J.B. Metzlersche Verlagsbuchhandlung, 1970), p.3-61.

"Heines frühe Kritiker." Der Dichter und seine Zeit. (Heidelberg: Lothar Stiehm Verlag, 1970), p.113-133.

Mebr als ein Liberaler: ïber Heinrich Heine. (Frankfurt and New York: Peter Lang, 1993).

"One Identity is not Enough: Heine's Legacy to Germans, Jews, and Liberals." Heinrich Heine and the Occident: Multiple Identities, Multiple Receptions. Ed. S.Gilman and P.Hohendahl. (Lincoln and London: University of Nebraska Press, 1991), p.19-41.

Hohendahl, Peter Uwe, Building a National Literature: The Case of Germany; 1830 -1870. Trans. Renate Franciscono. (Ithaca: Cornell University Press, 1989).

Holborn, Hajo, A History of Modern Germany, 1840-1945. (Princeton: Princeton University Press, 1969).

Hooten, Richard Gary, Heinrich Heine und der V ormärz. (Meisenheim am Glan: Verlag Anton Hain, 1978).

Johnson, Paul, The Birth of the Modern: World Society 1815-1830. New York: Harper Collins, 1991).

Jones, W.T., "Kant and the Nineteenth Century." A History of Western Philosophy. (Hardcourt Brace Jovanovich 1975). 
Kocka, Jürgen, "Bürgertum und bürgerlische Gesellschaft im 19. Jahrhundert: Europäische Entwicklungen und deutsche Eigenarten." Bürgertum im 19. Jabrbundert. Vol.I. Ed. Jürgen Kocka. (München: Deutscher Taschenbuch Verlag, 1988). p.11-78.

Künzel, Horst, "Lyrik als Herrschaftskritik: Zu drei Gedichten Heinrich Heines." Heine Jahrbuch (1973), 83-98.

Lukács, Georg, "Heine und der ideologische Vorbereitung der achtundvierziger Revolution." Aufbau. No.12 (1956), 103-118.

Mann, Thomas, "Notiz über Heine." Gesammelete Werke. Vol.X. (Oldenburg: Fischer Verlag, 1960), p.839.

Marcuse, Ludwig, "Heine and Marx: A History and a Legend." The Germanic Reriew. Vol.XXX. No.2. (1955), 110-124.

Nipperdey, Thomas, Germany from Napoleon to Bismarck. (Princeton: Princeton University Press, 1983).

Pawel, Emst, The Poet Dying. Heinrich Heine's Last Years in Paris. (New York: Farrar, Straus, and Giroux, 1995).

Prawer, S.S., Heine - The Tragic Satirist: A Study of the Later Poetry, 1827 -1856. (Cambridge: Cambridge University Press, 1961).

Reeves, Nigel, Heinrich Heine: Poetry and Politics. (Oxford: Oxford L'niversity Press, 1974).

Robertson, Ritchie, Heine. (New York: Grove Press, 1988).

Sagarra, Eda, Tradition and Revolution: German Literature and Society, 1830 -1890. (New York: Basic Books, 1971).

Sammons, Jeffrey L., Heinrich Heine. (Stuttgart: J. B. Metzlersche Verlagsbuchhandlung, 1991).

Heinrich Heine: A Modern Biography. (Princeton: Princeton University Press, 1979).

Six Essays on the Young German Novel. (Chapel Hill: University of North Carolina Press, 1972). 
Sheehan, James J., German History, 1770-1866. (Oxford: Oxford University Press, 1989).

Siemann, Wolfram, Die deutsche Revolution von 1848/49. (Frankfurt: Suhrkamp, 1985).

Treitschke, Heinrich von, History of Germany in the Nineteenth Century. Vols.IV, V, and VII. Trans. E. and C. Paul. (London: Jarrold and Sons, 1919).

Vierhaus, Rudolf, "Vormärz - ökonomische und soziale Krisen, ideologische und politische Gegensätze." Francia No.13. (1985). 355-368.

Wagner, Richard, Das Judentum in der Musik. (Weimar: Deutschvolkischer Verlag, 1914).

Walzel, Oskar, German Romanticism. Trans. Alma Lussky. (New York and London: G. P. Putnam's Sons, 1932).

Wemer, Hans-Georg, Geschichte des politischen Gedichts in Deutschland ion 1815 bis 1840. (Berlin: Akademie-Verlag, 1969). 